UNITED STATES GEOLOGIOAL SURVEY

$$
\text { BULLETIN } 51 \text { ? }
$$

RESULTS OF SPIRIT LEVELING IN

ALABAMA

1911

I $19.3: 517$ 


\section{DEPARTMENT OF THE INTERIOR \\ UNITED STATES GEOLOGICAL SURVEY GEORGE OTIS SMTTH, DIRECTOR}

\section{BUILETIN 517}

\section{RESUITS OF SPIRIT LEVELING IN ALABAMA}

\section{1}

R. B. MARSHALL, ChHef Geographer

Work done in cooperation with State of Alabama through the Geological Survey of Alabama, Eugeno A. Smith, State geologist

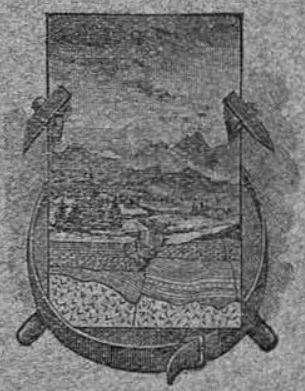

W ASHINGTON GOVERNMENT PRINTING OFFIQP

1912 

DEPARTMENT OF THE INTERIOR

UNITED STATES GEOLOGICAL SURVEY

GEORGE OTIS SMITH, DIRECTOR

\section{Bulletin 517}

\section{RESULTS OF SPIRIT LEVELING IN ALABAMA}

\section{1}

R. B. MARShaLL, Chief Geographer

\section{Work done in cooperation with State of Alabama through the Geological Survey of Alabama, Eugene A. Smith, State geologist}

ZIBRAFY

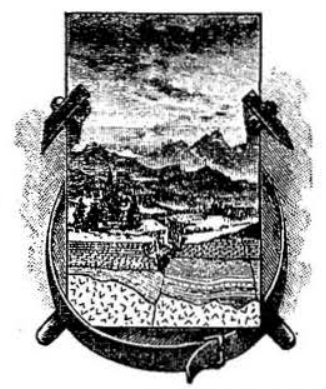

TEXAS TECHNOLOGICAL COLLEGE

WUSSOCK. TEXAS

$\mathrm{G} 30: 12$

WASHINGTON

GOVERNMENT PRINTING OFFICE

1912 



\section{CONTENTS.}

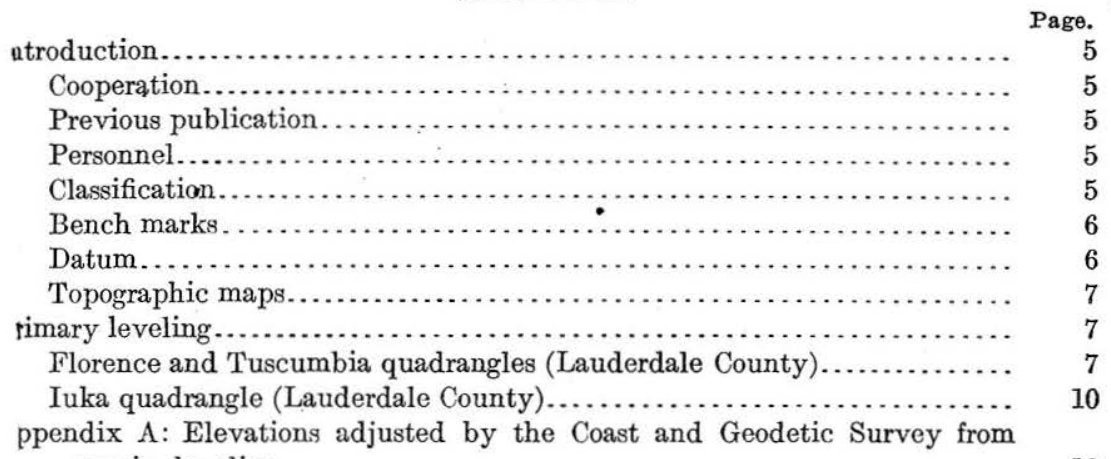

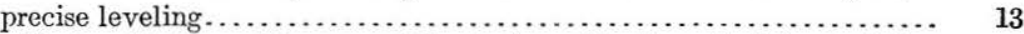

Barton, Bellamy, Bessemer, Birmingham, Brookwood, Calvert, Cuba, Cullman, Decatur, Deer Park, Demopolis, Epes, Eutaw, Florence, Grand Bay, Hillsboro, Huntsville, Iuka, Mobile, Powers, Rogersville, Scottsboro, Stevenson, Town Creek, Tuscaloosa, Tuscumbia, and Vinegar Bend quadrangles (Blount, Colbert, Cullman, Greene, Hale, Jackson, Jefferson, Lauderdale, Lawrence, Limestone, Madison, Mobile, Morgan, Sumter, Tuscaloosa, and Wash-

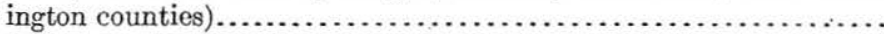

pendix B: Secondary elevations from records and topographic maps of the

United States Geological Survey and other useful elevations, including altitudes determined by vertical angles and other methods............ dex 5 6 6 7 7 7

\section{ILLUSTRATION.}

LATE I. Geological Survey bench marks. 




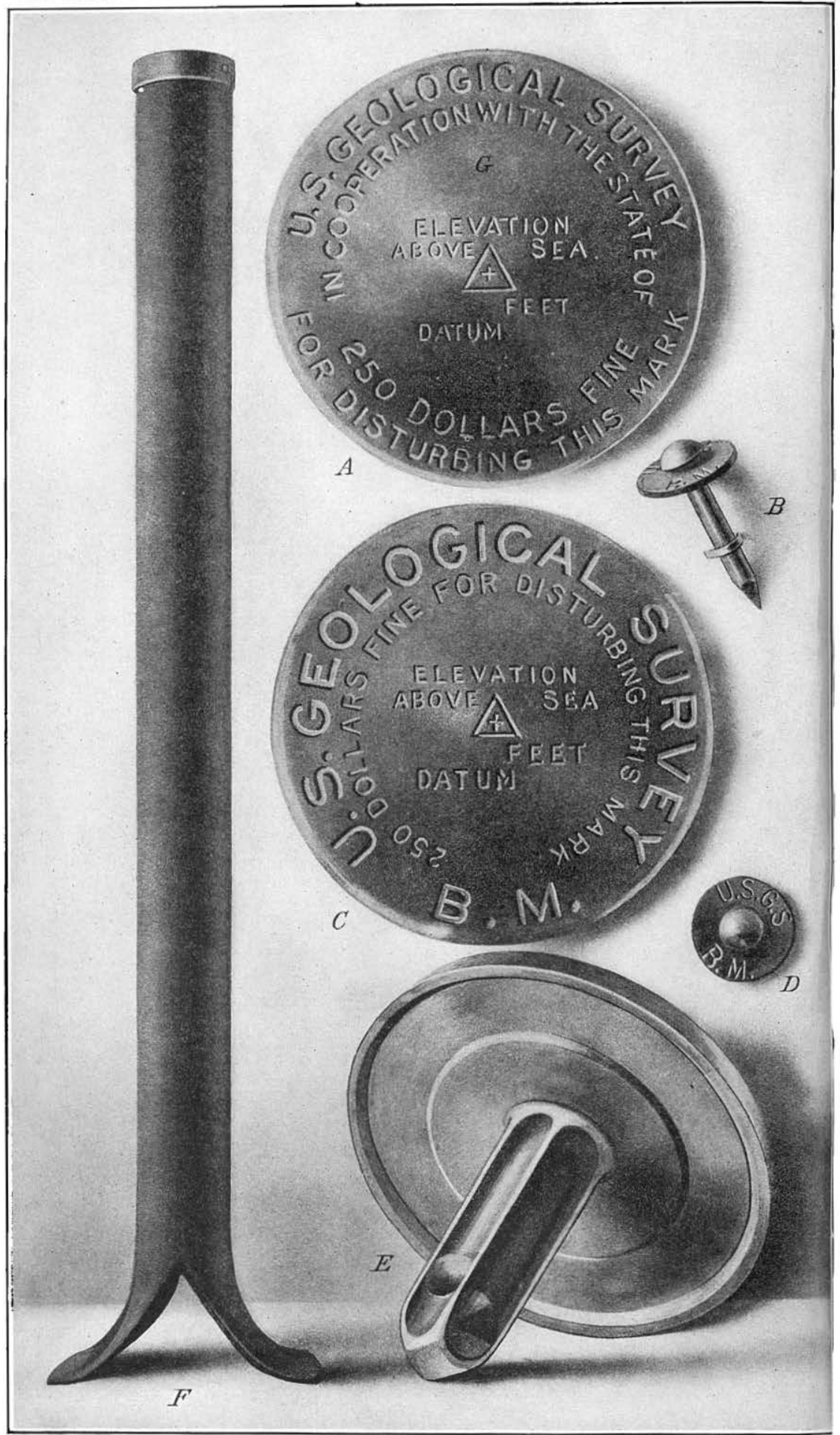

GEOLOGICAL SURVEY BENCH MARKS.

$A$, Tablet used in cooperating States. The State name is inserted at $G$.

$B$ and $D$, Copper temporary bench mark, consisting of a nail and copper washer.

$A, C$, and $E$, Tablets for stone or concrete structures.

$F$, Iron post used where there is no rock. 


\title{
RESULTS OF SPIRIT LEVELING IN ALABAMA, 1911.
}

\author{
R. B. Marshall, Chief Geographer.
}

\section{INTRODUCTION.}

Cooperation.-The State Geological Survey of Alabama contribted financially to the cooperative work.

Previous publication.-The following results of spirit leveling are upplemental to and in accord with the elevations contained in Bullen 441, and are in agreement with the 1907 adjustment of precise veling by the Coast and Geodetic Survey. The elevations have not een changed by the 1912 adjustment. Corrections to elevations of ench marks in Alabama in Bulletin 441 should be noted as follows:

nge 11: Bench mark 0.25 mile southeast of Blanche, an aluminum bolt stamped “ $760 \mathrm{~A}$," elevation of which was 748.286 , has been destroyed.

*ge 21: Elevation of bench mark 5 miles south of Fort Mitchell, an iron post stamped "Prim. Trav. Sta. No. 3, 1906. 304 ADJ 1907" should be 304.499 feet instead of 309.499.

tge 22: Permission has been granted for the removal of the bench mark at Crawford, an aluminum tablet stamped "452 ADJ 1907."

Personnel.-The field work of 1911 was done under the supervision Frank Sutton, geographer, under the general direction of R. B. arshall, chief geographer. Credit is given to the different levelen in the introduction to each list. The office work of computation, justment, and preparation of lists was done mainly by S. S. Gantt, geographer, under the general direction of E. M. Douglas, ographer.

Classification.-The elevations are classified as precise or primary, cording to the methods employed in their determination. For prese-level lines instruments and rods of the highest grade are used, ch line is run both forward and backward, and every precaution is ken to guard against error. The allowable divergence between the rward and the backward lines.in feet is represented by the formula $017 \sqrt{\mathrm{D}}$, in which $\mathrm{D}$ is the distance in miles between bench marks. or primary lines standard $Y$ levels are used; lines are run in cirits or are closed on precise lines, with an allowable closing error feet represented by $0.05 \sqrt{\mathrm{D}}$, in which $\mathrm{D}$ is the length of the circuit miles, sufficient care being given to the work to maintain this stand- 
ard. For leveling of both classes careful office adjustments are made, the small outstanding errors being distributed over the lines.

Bench marks.-The standard bench marks are of two forms. The first form is a circular bronze or aluminum tablet $(C$ and $E, \mathrm{Pl}$. I), $3 \frac{1}{2}$ inches in diameter and one-fourth inch thick, having a 3-inch stem, which is cemented in a drill hole in solid rock in the wall of a public building, a bridge abutment, or other substantial masoniy. The second form $(F, \mathrm{Pl} . \mathrm{I})$, used where masonry or rock is not available, consists of a hollow wrought-iron post $3 \frac{1}{2}$ inches in outer diameter and 4 feet in length. The bottom is spread out to a width of 10 inches in order to give a firm bearing on the earth. A bronze or aluminum-bronze cap is riveted over the top of the post, which is set about 3 feet in the ground. A third style of bench mark, with abbreviated lettering ( $B$ and $D, \mathrm{Pl}$. I), is used for unimportant points. This consists of a special copper nail $1 \frac{1}{2}$ inches in length driven through a copper washer $\frac{7}{8}$ inch in diameter. The tablets as well as the caps on the iron posts are appropriately lettered, and cooperation by States is indicated by the addition of the State name $(G, \mathrm{Pl}$. I).

The numbers stamped on the bench marks described in the following pages represent the elevations to the nearest foot as determined by the levelman. These numbers are stamped with $\frac{3}{16}$-inch steel dies on the tablets or post caps, to the left of the word "Feet." The office adjustment of the notes and the reduction to mean sea level datum may so change some of the figures that the original markings are 1 or 2 feet in error. It is assumed that engineers and others who have occasion to use the bench-mark elevations will apply to the Director of the United States Geological Survey, at Washington, D. C., for the adjusted values, and will use the markings as identification numbers only.

Datum.-All United States Geological Survey elevations are referred to mean sea level, which is the level that the sea would assume if the influence of winds and tides were eliminated. This level is not the elevation determined from the mean of the highest and the lowest tides, nor is it the half sum of the mean of all the high tides and the mean of all the low tides, which is called the half-tide level. Mean sea level is the average height of the water, all stages of the tide being considered: It is determined from observations made by means of tidal gages placed at stations where local conditions, such as long, narrow bays, rivers, and like features, will not affect the height of the water. To obtain even approximately correct results these observations must extend over at least one lunar month, and if accuracy is desired they must extend over several years. At ocean stations the half-tide level and the mean sea level usually differ but little. It is assumed that there is no difference between the mean sea level as determined from observations in the Atlantic Ocean, the Gulf of Mexico, or the Pacific Ocean. 
The connection with tidal stations for bench marks in certain areas that lie at some distance from the seacoast is still uncertain, and this fact is indicated by the addition of a letter or word to the right of the word "Datum" on tablets or posts. For such areas corrections for published results will be made from time to time as the precise-level lines of the United States Geological Survey or other Government organizations are extended.

Topographic maps.-Maps of the following quadrangles, wholly or partly in Alabama, have been published by the United States Geological Survey up to July 1, 1912. They may be obtained at 5 cents each or $\$ 3$ a hundred on application to the Director of the Survey, at Washington, D. C.

Anniston.

Ashland.

Bessemer. ${ }^{1}$

Bessemer special. ${ }^{1}$

Birmingham. $^{2}$

Birmingham special. ${ }^{2}$

Brookwood.

Clanton.

Columbiana. ${ }^{1}$

Columbus (Ala.-Ga.).

Cullman.

Dadeville.

Fort Payne (Ala.-Ga.).

Gadsden.

Huntsville (Ala.-Tenn.).

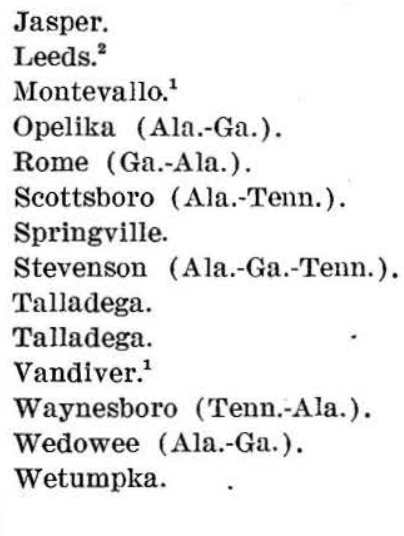

PRIMARY LEVELING.

Florence and Tuscumbia quadrangles.

LAUDERDALE COUNTY.

The following elevations were determined by primary leveling based upon bench marks of the United States Corps of Engineers and the Coast and Geodetic Survey.

The leveling was done by C. W. Arnold in 1911.

The State cooperated in the work.

\section{FLORENCE QUADRANGLE.}

Point near Florence west along highway 3 miles, thence north along highway to point near Tennessee State line, thence southeast to Pruitton, thence northeast to Iron City, Tenn.

Florence, north side of Tennessee River, in north abutment of railroad and wagon bridge, on east pedestal stone near northwest corner; copper bolt, marked "B. M. 432 "

Feet. 432. 064

551.906

corence, in southeast corner of courthouse yard; iron post stamped " Prim. Trav. Sta. No. 1, 552 "

${ }^{1}$ Bessemer special, Columbiana, Montevallo, and Vandiver sheets show Bessemer quadrangle on larger scale.

2 Birmingham special and Leeds sheets, on scale of $1: 62500$, have been reduced and form parts of Birmingham sheet, on scale of $1: 125000$. 
Florence, 2.5 miles west of, at top of hill, in large oak tree north of road; copper nail, stamped " 504 B. M."

Florence, 4.1 miles west of, 10 feet south of road forks; iron post stamped " Prim. Trav. Sta. No. 7, 554"

Florence, 5 miles northwest of, 20 feet southeast of road forks, in root of small tree; copper nail, stamped “B. M. 573"

Florence, 5.3 miles northwest of, 30 feet north of road forks, in root of oak tree; copper nail, stamped "B. M. 586 "

Florence, 6.6 miles northwest of, 20 feet east of road forks, in bole of small oak tree; nail, marked “B. M. 544.6"

Florence, 8.2 miles northwest of, 6 feet west of road forks; iron post stamped " 4741911 ”

Florence, 10 miles northwest of, 200 feet east of Little Cypress Creek, 100 feet south of road, in limestone ledge; aluminum tablet stamped "490 1911"

Florence, 11.1 miles northwest of, 50 feet west of road forks, in root of small hickory tree; copper nail, stamped " 608 B. M."

Florence, 12.6 miles northwest of, 200 feet west of road forks, in root of large oak stump 3 feet north of road; copper nail, stamped " 629.4 B. M."

Florence, 13.6 miles northwest of, on south end of west abutment of wagon bridge over Cypress Creek; chiseled square, marked "B. $\mathrm{M}$. 512. 1 "

Florence, 14.1 miles northwest of, 10 feet southwest of road forks, in root of small oak tree; copper nail, stamped " 595.7 B. M."

Florence, 15.4 miles northwest of, 30 feet northwest of road forks, in root of oak stump; copper nail, marked " 587.2 B. M."

Florence, $\mathbf{1 5 . 9}$ miles northwest of, in southwest corner of road crossing; iron post stamped " Prim. Trav. Sta. No. 6, 605"

Florence, 17.5 miles northwest of, 40 feet north of road forks, in root of small oak tree west of road; copper nail, stamped " 632 B. M."--

Florence, 18.3 miles northwest of, northeast corner of crossroads; iron post stamped " 6591911 "

Florence, 19.8 miles northwest of, in southeast corner of crossroads, in root of small oak tree; copper nail, stamped " 670.2 B. M."

Florence, 20.3 miles northwest of, 120 feet north of small drain, in root of chestnut tree, east of road; copper nail, stamped " 625 B. M."

Florence, 21.5 miles northwest of, in root of hickory tree in triangle of road forks; copper nail, stamped " 642.4 B. M."

Pruitton, 7.6 miles west of, 10 feet southeast of road forks, 1 mile south of Tennessee State line; iron post stamped " Prim. Trav. Sta. No. 5, 652",

Pruitton, 6.5 miles west of, 200 feet east of stream crossing, 6 feet south of road,. in root of oak tree; copper nail, stamped " 657.3 B. M.",

Pruitton, 5.6 miles west of, 50 feet east of Cypress Creek, in root of oak tree on north side of road; copper nail, stamped " 612.5 B. M."-

Pruitton, 4.7 miles west of, in small oak tree north of road; copper nail, stamped " 656.1 B. M."

Pruitton, 3.7 miles west of, 15 feet southeast of road forks, in root of twin oaks; copper nail, stamped "723.7 B. M."

Pruitton, 3.3 miles west of, on Savannah road, in southwest cormer of crossroads; iron post stamped " 7191911 "

Feet.

504. 14

554. 119

572. 93

5S5. 73

544. 66

473. 904

489. 856

608. 14

629. 50

512. 22

594. 78

5\$6. 31

604. 550

631. 09

658. 693

669. 34

624. 15

641. 57

650. 962

655. 32

722. 85

719. 291 
Pruitton, 2.5 miles west of, 30 feet south of crossroads, at top of hill, in root of oak tree; copper nail, stamped " 765.5 B. M."

Feet.

764. 74

Pruitton, 1.5 miles west of, 6 feet south of road, 100 feet south of stream, on limestone ledge; chiseled square, marked "B. M. 594.4"-

Pruitton, 0.8 mile west of, in root of gum tree north of road; copper nail, stamped “549.9 B. M."

Pruitton, in northeast corner of Mr. Pruitt's yard ; iron post stamped "Prim. Trav. Sta. No. 4, 562 "

593. 64

549.13

561.030

Pruitton, 1.7 miles north of, 100 feet south of milepost No. 295, on rock ledge west of railroad; point of rock, marked " 692.2 B. M."---

Iron City, in northwest corner of west abutment of wagon bridge over Shoal Creek; bronze tablet stamped " 558 "

691.43

558. 252

Iron City south along highway to Killen, thence southwest 1.9 miles to bench mark of the United States Corps of Engineers.

Iron City, 1.3 miles east of, 10 feet northwst of road forks, in root of

- oak tree; copper nail, stamped "i04.1 B. M."

704.39

Iron City, 2.1 miles east of, 20 feet west of Wolf Creek, 100 feet south of road forks, in root of elm tree; copper nail, stamped " 569.2 B. M."

Iron City, 3 miles southeast of, 10 feet north of road, on rock ledge; point of rock, marked "B. M. 631.7 " -

Iron City, 4.2 miles southeast of, in triangle at road forks ; iron post stamped " 7671911 "

Iron City, 5.4 miles southeast of, 20 feet northwest of road forks, 600 feet south of house, in root of oak tree; copper nail, stamped " 774.8 B. M."

Green Hill, 100 feet south of store; iron post stamped "Prim. Trav. Sta. No. 3, $767 "$

Green Hill, 0.4 mile east of, 10 feet southeast of road forks, in root of tree; copper nail, stamped " 769.8 B. MI."

Green Hill, 1.7 miles south of, 6 feet west of road, in root of oak tree; conper nail, stamped " 699.7 B. M."

Green Hill, 4 miles south of, 20 feet north of crossroads, in root of oak tree; copper bolt, staniped " 765.9 B. M."

Green Hill, 4.6 miles sonth of, in southeast corner of crossroads; iron post stamped " 7531911 ".

Green Hill, 5.5 miles south of, 100 feet southeast of store, in root of oak tree; copper nail, stamped " 727.2 B. M."-

Green Hill, 6.4 miles sonth of, 10 feet west of road forks, in root of oak tree; copper nail, stamped " 697.5 B. M."

Killen, 200 feet northeast of post office, in southeast corner of yard; iron post stamped "Prim. Trav. Sta. No. 2, 622"

Killen, 1.9 miles southwest of, on southwest corner of lock No. 6 of canal, near heelpost; copper bolt set in rock (U. S. Corps of Engineers b. m.)

631.95

767.438

775.12

766. 921

770.19

700.11

766. 30

753. 696

727. 65

697.95

622. 125

471. 322 .

Point near Florence southeast about 9 miles to point north of Leighton.

Florence, on northeast corner of south abutment of railroad and wagon bridge over Tennessee River, in bridge seat; copper bolt, marked " 441.4 " (U. S. Corps of Engineers b. m.) -

Florence, 1.7 miles south of, in southeast corner fence post at crossroads; copper nail, stamped " 513.2 B. M." $46783^{\circ}-$ Bull. $517-12-2$ 
Florence, 2.S miles southeast of, 50 feet south of road, in root of chiniberry tree; copper nail, stamped " 521.5 B. M."

Florence, 4.2 miles southeast of, in southeast quadrant of crossroads; iron post stamped "Prim. Trar. Sta. No. 15, 522 "

Florence, 5.3 miles southeast of, 150 feet north of house, in root of tree north of road; copper nail, stamped " $5+4.6$ B. MI."

Florence. 7 miles southeast of, on south end of stone culvert; chiseled square, marked “B. M. 551.5”

Florence, 8.4 miles sontheast of, in northwest quadrant of crossroads; iron post stamped "Prim. Trav. Sta. No. 14, 607"

Florence, 9.5 miles sontheast of, 200 feet south of second-class road to east, in root of oak tree on west side of road; copper nail, stamped "549.7 B. M."

Florence. 10.3 miles southeast of, in southwest quadrant of crossroads, in root of small tree; copper nail stamped "5T0.7 B. M."-.-

Florence, 11.3 miles southeast of, in northeast quadrant of crossroads, in root of oak tree; copner nail, stamped " $5 \$ 9.3$ B. M."-----

\section{TUSCUMBIA QUADRANGLE.}

\section{At Leighton.}

Leighton, in northwest corner of King building, serenteenth brick from bottom; copper bolt lended in brick, marked "U. S. B. MI.", stamped " 572 "

Tuscumbia south 4.4 miles (single spur line to be extended).

Tuscumbia, in southwest corner of courthouse; copper bolt stanped "U. S. B. M."

Tuscumbia, at northeast corner of courthouse yard ; iron post stamped "Prim. Trav. Sta. No. 8, 477"

Tuscumbia, 1.5 miles south of, on north end of stone culvert; point of rock, marked " B. M. 428.8 "

Tuscumbia, 2.7 miles south of, in root of gum tree east of road; copper nail, stamped " 448 B. M."

Tuscumbia, 3.8 miles south of, 30 feet southwest of road forks, in root of beech tree; copper nail, stamped " 499.6 B. M."

Tuscumbia, 4.4 miles south of, at north base of mountain, 15 feet west of road, in top of large pine stump; copper nail, stamped "544.5 B. M."

Feet.

521.44

521.514

544. 60

551.50

607. 051

549.62

570. 61

$589.29^{\circ}$

480.160

477. 396

428. 761

447. 997

499. 611

544.458

\section{Iuka quadrangle.}

\section{IAUDERDALE COLNTY.}

The following elevations are based on bench marks of the Coast and Geodetic Survey and U. S. Corps of Engineers in the vieinity of Iuka.

The leveling was done in 1911 by J. B. Metcalfe, jr. IUKA QUADRANGLE.

Point 1.2 miles northwest of Shaws to point 3 miles north of Shaws, thence east along highways to point 5 miles east of Shaws.

Shaws, 30 feet northeast of branch crossing main road. 400 feet west of store, 300 feet north of blacksmith shop, 20 feet east of road; iron post stamped " 406 " 
Shaws, 1 mile northeast of, 50 feet south of road forks, near head of Shaws Branch, in northeast corner of drain forks, in root of gum tree; copper nail, marked " 508.1 "

Shaws, 1.9 miles northeast of, 15 feet east of old shop, 15 feet west of road, 300 feet north of one-story frame dwelling owned by J. B. Smith, in root of 6 -inch red oak-tree; copper nail, marked " 650.3 "-

Shaws, 2.5 miles northeast of, at $T$ road south, 50 feet southwest of mail box and 20 feet south of road ; iron post stamped " 654 ".

Feet.

508. 14

650. 30

653. 852

Shaws, 3.6 miles northeast of, 50 feet east of road forks northeast, 6 feet south of road, in root of 36 -inch white oak tree; copper nail. marked " 677.9 "

Shaws, 5 miles east of, 25 feet southeast of second-class road west, 250 feet north of road forks to south, in top of stump about 3 feet high and 2 feet in diameter ; copper nail, marked " 704.4 "

Bumpas Creek school and church south along Bumpas Creek road to Riverton.

Bumpas Creek, 200 feet northwest of schoolhouse and church, 75 feet south of one-story frame dwelling, 15 feet west of road, in root of 15-inch red oak tree; copper nitil, marked " 501.8 "

Bumpas Creek schoolhouse, 1.2 miles south of, 30 feet south of drain crossing, 8 feet west of road, in root of 15-inch gum tree; nail, marked " 476.4"

Bumpas Creek schoolhouse, 2.1 miles south of, at A. V. Beaver's water mill, about 200 feet south of dam across creek, 15 feet south of road and 3 feet north of blacksmith shop; iron post stamped " 462 "

501.86

476. 50

462. 588

Bumpas Creek schoolhouse, 3.3 miles south of, in northwest corner of road and creek crossing, in root of gum tree stump; copper nail, marked " 421.0 "

Waterloo, about 0.9 mile north of, 25 feet west of intersection of Waterloo-Bumpas Creek and Waterloo-Stout roads, 7 feet east of trunk of $4 \frac{1}{2}$-foot white oak tree, in its root; copper nail, marked " $421.6 "$

Waterloo, about 0.3 mile south of, 75 feet east of intersection of Waterloo-Walnut Grove and Waterloo-Riverton roads, 25 feet southeast of gate, 10 feet north of road ; iron post stamped " 393 "-

Riverton, about 0.5 mile below railroad station, 27 feet from river bank; copper bolt leaded in stone post 4 feet long, top 6 inches above the ground (U. S. Corps of Engineers bench mark) --------

Point 2.1 miles of Waterloo north along Second Creek road to a point 8.7 miles northeast of Waterloo.

Waterloo, 2.1 miles north of, just at top of hill, 75 feet northwest of one-story frame dwelling, 10 feet east of road, at mouth of hollow, in root of 16-inch chestnut tree; copper nail, marked " 425.6 "

Waterloo, 3.3 miles northeast of, 200 feet northeast of house, opposite $T$ road east, 7 feet west of road, 200 feet south of drain crossing, in root of 15 -inch walnut tree; copper nail, marked " 443.8 "

Waterloo, 4.3 miles northeast of, at top of hill, 30 feet northeast of old $\log$ house, 18 feet west of road; iron post stamped " 533 " 
Waterloo, 6 miles northeast of, in northwest corner of Second Creek and road crossing, 20 feet north of water's edge, in root of birch tree; copper nail, marked " 459.2 "

Feet. 459. 23

Waterloo, 7.7 miles northeast of, 300 feet northwest of one-story frame dwelling, at top of hill, between road and Second Creek, 15 feet west of road, 150 feet south of small cemetery, in root of 12-inch elm tree; copper nail, marked " 507.7 "

507.82

Waterloo, 8.7 miles northeast of, about 800 feet southwest of road forks to east, 150 feet east of one-story frame dwelling at bend of road, 75 feet north of creek branch, 15 feet east of road; iron post stamped " 514 " 


\section{ELEVATIONS ADJUSTED BY THE COAST AND GEODETIC SURVEY FROM PRECISE LEVELING.}

Barton, Bellamy, Bessemer, Birmingham, Brookwood, Calvert, Cuba, Cullman, Decatur, Deer Park, Demopolis, Epes, Eutaw, Florence, Grand Bay, Hillsboro, Huntsville, Iuka, Mobile, Powers, Rogersville, Scottsboro, Stevenson, Town Creek, Tuscaloosa, Tuscumbia, and Vinegar Bend quadrangles.

BLOUNT, COLBERT, CULLMAN, GREENE, hALE, JACKSON. JEFFERSON, LAUDERdAL, LAWRENCE, LIMESTONE, MADISON, MOBILE, MORGAN, SUMTER, TUSCALOOSA, AND VASHINGTON COUNTIES.

The following descriptions and elevations are taken from reports of the Coast and Geodetic Survey and are republished by permission of the Superintendent of that bureau. The bench marks were established by the Coast and Geodetic Survey and by the U. S. Corps of Engineers from precise leveling, and were included in the 1907 adjustment by the Coast and Geodetic Survey. The elevations were not changed by the 1912 adjustment.

\section{STEVENSON 30' QUADRANGLE.}

Bridgeport along Nashville, Chattanooga \& St. Louis Ry. to Stevenson, thence along Southern Ry. to Hollywood.

Bridgeport, at east end of the Nashville, Chattanooga \& St. Louis Ry. bridge over Tennessee River, south side of abutment, on large coping stone below bridge seat block, 0.65 meter east of west face, 0.165 meter north of edge, 1.49 meters below south rail; bottom of a square hole cut in stone, lettered U. S. C. \& G. S. (C. \& G. S. C.) _ Bridgeport, at east end of east bridge over Tennessee River, abutment on south side, on southwest corner of the coping, below bridge seat block. Not marked. (U. S. Corps of Engineers b. m.)

Bolivar, 446 meters east of Nashville, Chattanooga \& St. Louis Ry. station platform, on south end of west abutment of bridge over Widow Creek, 2.04 meters south of and 1.34 meters below south rail, in large bridge seat block, 0.15 meter north of its south face and 0.25 meter east of its west face; bottom of a square hole, cut in stone, lettered "U. S. C. $\square$ \& G. S." (C. \& G. S. "D") Stevenson, 1 mile west of, on south wall of west abutment of Southern Ry. bridge over Crow Creek, in large stone just below coping, 1.7 meters above ground, 0.64 meter below top of pier, and 15 inches west of the east face; horizontal chisel mark cut in end of copper bolt leaded horizontally into stone, lettered “U. S. C. $\ominus$ G. S." (C. \& G. S. "E")

Feet. 621.484

621.495

616. 517

605.546 
Cedar Grove, 225 meters west of siding of Southern Ry., on second step of retaining wall on east side, at south end of bridge $282.9 \mathrm{~A}, 1.5$ meters south and 1.1 meters below south (?) rail, 8 inches east of west face and 13 inches north of south face of second step, 7 inches south of the first step; bottom of square hole, cut in stone, lettered “U. S. C. $\square$ G. S." (C. \& G. S. “F”)

Fackler, 0.7 meter west of, on the east end at the north side of Southern Ry. bridge 287.1 $\Lambda$, over Dole Branch, on second step of east retaining wall, 2.45 meters north of and 1.54 meters below north rail, 7 inches south of the north face and 11 inches east of west face of step; bottom of square hole, cut in stone, lettered "U. S. C. $\square$ \& G. S." (C. \& G. S. "G")

Fackler, 1.75 miles west of, on south side of east end of east abutment of Southern Railway bridge over Mud Creek, 1.45 meters south and 1.4 meters below south rail, on coping under bridge-seat block, 4 inches from south face and 0.45 meter east of west face; bottom of square hole, cut in stone, lettered "U. S. C. $\square$ \& G. S." (C. \& G. S. " $\mathrm{H}$ ")

Hollywood, north of railway station, 85 meters north of track, in east face of G. W. Chapman's Hotel, in seventh course of stonework below top of foundation of brick chimney, 1.18 meters above ground, 8.75 inches south of end of stone and corner of chimney; horizontal chisel mark in end of copper bolt leaded horizontally into brick, lettered “U. S. C. $\ominus$ \& G. S." (C. \& G. S. “ I") -

Feet. 607. 859

601.516

604.779

640. 287

SCOTTSBORO QUADRANGLE.

\section{Hollywood along Southern Ry, to Brownsboro.}

Hollywood, Jackson County, 3 miles west of, north of Southern Ry. track, at east end of bridge $295.2 \mathrm{~A}, 2.1$ meters north of and 1.28 meters below north rail, on second step of retaining wall, 8 inches east of west face and 5 inches south of north face; bottom of square hole cut in stone, lettered "U. S. C. $\square$ \& G. S." (C. \& G. S. " $J$ ")

Scottsboro, 350 meters south of Southern Railway station, in west wall of courthouse, 10 feet north of southwest corner, midway between first and second windows, in water table of chimney offset, 2.25 feet above ground; horizontal chisel mark cut in end of copper bolt leaded horizontally into stone wall, lettered "U. S. C. $\square$ \& G. S." (C. \& G. S. "K"

Larkinsville, 1.3 miles east of, at east end of deep stone cut of Southern Ry., 25 meters west of road crossing, 0.35 meter above and 2.23 meters north of north rail; horizontal chisel mark cut in end of copper bolt leaded horizontally into a rock in place, lettered “U. S. C. $\ominus$ \& G. S." (C. \& G. S. "L")

Larkinsville, 0.5 mile west of, west side at south end of Southern Ry. bridge $303.6 \mathrm{~A}, 2.45$ meters south of and 1.36 meters below south rail, on second step below coping of retaining wall, 0.2 meter west of east face and 0.15 meter north of the south face; bottom of a square hole cut in stone, lettered “U. S. C. $\square$ \& G. S." (C. \& G. S. " $\mathrm{M}$ ")

Lin Rock, 213 meters west of Southern Ry. station, on south end of east abutment of a bridge or cattle guard at west end of village, at right of way fence, 1.15 meters south of and 0.75 meter below
651.853

630. 160

650. 732 
south rail, on end stone of coping, 6 inches north of south face and 7 inches east of west face; bottom of a square cut in stone, lettered "U. S. C. $\square$ \& G. S." (C. \& G. S. "N")

Feet.

614. 669

Lim Rock, 1.8 miles west of, in north wall of deep stone cut of Southern Ry., about one-quarter of the length of cut from east end, 166 meters west of road crossing, 2.55 meters north of and 0.76 meter above north rail; horizontal chisel mark cut in end of a copper bolt leaded horizontally into stone, lettered "U. S. C. $\ominus$ \& G. S." (C. \& G. S. "O")

Dossett, about 2 miles from Swearengin, in T. 5 S., R. 4 E., on north side of Woodville and Guntersville highway, at foot of Gunter Mountain, at point where road leaves Wrights Cove Creek and ascends mountain, 46 meters south of creek and 23 meters east of road, on high and prominent point of large sheet of rock; top of a copper bolt leaded vertically, lettered "U. S. C. $\square$ \& G. S." (C. \& G. S. "P")

Swearengin, T. 5 S., R. 4 E., on north side of W. B. Huggins's residence on Woodville and Guntersville road, 500 feet north of main road crossing, 26 feet west of the center of the road, in stone chimney, 6.5 inches west of the northeast corner and 32 inches above ground; horizontal chisel mark cut in the end of copper bolt leaded horizontally, lettered “U. S. C. \& G. S.” (C. \& G. S. “Q”) _._.

Gunter triangulation station, near Swearengin, T. 5 S., R. 4 E., on top of a gently rounded hill (known as Gunter Mountain) covered with a dense growth of brush and small timber; on land of Mrs. L. Gideon, 1.2 miles N. $75^{\circ}$ E. from main road crossing at Swearengin, one-quarter mile N. $85^{\circ}$, from Prospect Church; bottom of a square cut in southwest quarter of cross on top of stone lettered "U. S. C. S." marking the triangulation point Gunter (C. \& G. S. "Gunter")

Gunter N.; bottom of square cut in southwest quarter of the cross on a reference stone 6 feet north of the stone marking the triangulation station Gunter, described above (C. \& G. S. "Gunter N") --- 1, 353.120

Gunter S.; bottom of square cut in southwest quarter of cross on a reference stone 6 feet south of the stone marking the triangulation station Gunter, described above (C. \& G. S. "Gunter S") -_._._- 1, 352.910

Gunter E., bottom of square cut in southwest quarter of cross on a reference stone 6 feet east of the stone marking the triangulation station Gunter, described above (C. \& G. S. "Gunter E.") --_-_-- 1, 352.933

Gunter W., bottom of square cut in southwest quarter of cross on a reference stone 6 feet west of the stone marking the triangulation station Gunter described above (C. \& G. S. "Gunter W") -_._-_-_ 1, 352.917

Woodville, on right of way of Southern Ry., opposite station and in line with the west side of the platform, 8 paces south of south rail of main track; bottom of a square hole cut in top of limestone post 30 inches long, set with 7 inches projecting above the ground and lettered "U. S. $\square$ B. M." (C. \& G. S. J-2) ; sub bench mark is on north side of post, 0.2952 meter below surface bench mark

614. 633

Woodville, about 500 feet west of station, on north side of west bridge seat of small trestle, in projecting end of second course of masonry from top, about 6 inches from north end 8 inches from east edge of stone; top of copper bolt, leaded vertically into stone, lettered "U, S, $\ominus$ B. M." (C. \& G. S. K-2) -. 
Woodville, 1 mile west of, near center of big fill, 25 feet below surface of grade, on arched stone waterway, 9 telegraph poles west of mile pole $314 \mathrm{~A}$, in west stone on north side of waterway, 1 foot from north side and 9 inches from east side of stone; copper bolt (C. \& G. S. L-2)

Woodville, 2 miles west of, on north side of east end of trestle 315.3A over Paint Rock River, 5 inches from east and south edges of stone supporting steel frame work of trestle; bottom of square hole (C. \& G. S. 1)

Paint Rock, on west abutment of trestle $318.1 \mathrm{~A}$, west of station, in top rock at north end of masonry, 6 inches from north and east edges; copper bolt (C. \& G. S. M-2)

Gurley, about 275 feet west of station, 7 paces south of south rail of main track of Southern Ry., across tracks from third telegraph pole west of station, 30 paces east of switch stand to siding; square hole in top of limestone post 30 inches long, lettered "U. S.

B. M." (C. \& G. S. N-2)

Gurley, 2 miles west of, on south side of east abutment of trestle $324.0 \mathrm{~A}, 4 \frac{1}{2}$ inches from south and 5 inches from west edge of large stone at south end; bottom of square hole (C. \& G. S. t. b. m. 8) ---

Brownsboro, on right of way of Southern Ry., about 30 feet west of and across tracks from station, 5 paces from north rail, 5 feet east of first telegraph pole west of station; square hole in top of limestone post 30 inches long, lettered "U. S. $\square$ B. M." (C. \& G. S. $\mathrm{O}-2)$

Brownsboro, 0.5 mile west of, on south side of east abutment to trestle 328.1 over Flint River, 18 inches south of south rail and 5 inches from south and west edge of large stone just beneath rails; bottom of square hole (C. \& G. S. t. b. m. 12)

Feet.

615. 910

603. 676

597.314

643.456

616.185

HUNTSVILLE QUADRANGLE.

Huntsville along Southern Ry. to Decatur, thence south along Louisville \& Nashville R. R, to Flint.

Fearns, 0.4 mile west of, in long cut, near center of top surface of large rock in place between railroad track and milepost $335 \mathrm{~A}, 1.7$ meters from milepost, about 8 feet above level of railroad grade; copper bolt (C. \& G. S. P-2)

Huntsville, on doorsill of corner entrance to city hall, corner of Clinton and Washington Streets; center of horseshoe mark (C. \& G. S. "City")

Huntsrille, on city hall, near center of third stone from easternmost of four large doors on Clinton Street side of building, in fourth course from sidewalk; copper bolt (C. \& G. S. Q-2)

Madison, 3 miles east of, on south side of west abutment of trestle 345.7A 4 inches from south and west edges; copper bolt (C. \& G. S. R-2)

Madison, near courthouse, just inside railway right of way, 75 feet west of station across tracks, 30 feet from south rail of main track, 6 feet north of small tree on boundary of right of way; square hole in top of limestone post 30 inches long lettered "U. S. $\square$ B. M." (C. \& G. S. S-2)

802. 391

635.829

(38. 903

619. 731

Greenbrier, 1 mile east of, in east abutment of trestle at mile pole $353 \mathrm{~A}$, on northeast one of four caps to abutments, in second stone from top, 8 inches from southeast corner, at edge formed by the curved surface of cap; copper bolt. (C. \& G. S. T-2) 
Belle Mina, 0.5 mile east of, on south side of east abutment of trestle $355.8 \mathrm{~A}$ over Limestone Creek, 7 inches from outer corner; bottom of square hole (C. \& G. S. t. b. m. 38)

Belle Mina, on Southern Ry. right of way, 50 feet west of station, 7 paces south of south rail of main track; bottom of square hole cut in top of 30 -inch limestone post, lettered "U. S. $\square$ B. M." (C. \& G. S. U-2)

Belle Mina, 1 mile west of, on north side of east pier of trestle $357.3 \mathrm{~A}$, 5 inches from north and east edges of pier; bottom of square hole (C. \& G. s. t. b. m. 39)

Flint, 1.5 miles south of, on west side of north abutment of trestle 4 , in top surface of third stone from south end, 5 inches from north edge of stone; copper bolt, lettered "U. S. $\ominus$ B. M." (C. \& G. S. $\mathrm{V}-2)$

Feet.

585.233

600.582

572.996

\section{HUNTSVILLE 30' QUADRANGLE (DECATUR 15' QUADRANGLE).}

\section{At Decatur.}

Decatur, 500 feet west of Southern Ry. bridge across Tennessee River, on railroad and highway bridge across Southern Ry. tracks on Market Street, on west side of north abutment, on second stone from ground, 9 inches from west and south edges of stone; bottom of square hole, lettered “U. S. $\square$ B. M." (C. \& G. S. M-3) --_---

Decatur, on First National Bank Building, at corner of Bank and Pond streets, on pedestal stone supporting east column of portico, on southeast side of column and corner toward both streets; bottom of square hole, lettered “U. S. $\square$ B. M.” (C. \& G. S. N-3)

Decatur, on portico of south entrance to county courthouse, at east end of portico, 9 feet east of center of entrance, on stone sill, 7 inches from main wall, on middle line of stone; bottom of square hole, lettered “ U. S. $\square$ B. M.” (C. \& G. S. O-3)

578.065

\section{Near Decatur.}

Decatur, on south abutment of railroad bridge, on down-river end of south of river shore and 0.8 foot above water at medium stage; highest point in square cut on rock (U. S. Corps of Engineers t. b. m. 176)

Decatur, on south abutment of railroad bridge, on down-river end of abutment, 6 inches south of river face of stone, in ninth course of masonry from top, $3 \frac{1}{2}$ feet above ground; copper bolt, lettered “U. S. $\odot$ P. B. M." (U. S. Corps of Engineers p. b. m. 50)

Decatur, on draw pier of railroad bridge across Tennessee River, on downstream side of draw, inside of rack; copper bolt, lettered “U. S. $\odot$ P. B. M." (U. S. Corps of Engineers p. b. m. 15)

Decatur, opposite, in second pier from north end of bridge, on upriver end of pier; copper bolt, lettered "U S. $\odot$ P. B. M." (U. S. Corps of Engineers p. b. n. 52)

538. 913

556. 416

565. 660

568. 219

\section{HILLSBORO QUADRANGLE.}

Trinity west along Southern Ry. to Hillsboro.

Trinity, on stone foundation of water tank, about 25 feet east of center of main track, on stone projecting under northeast corner of tank; bottom of square hole, lettered “U. S. $\square$ B. M.” (C. \& G. S. P-3)

$46783^{\circ}-$ Bull. $517-12-3$ 
Hillsboro, on two-story brick store building known as Robinsón Block, south of and across street from Southern Ry. station, on front sill, $3 \frac{1}{2}$ feet from northwest corner of building, 8 inches east of jamb at northwest corner, and 8 inches from front edge of sill; bottom of square hole, lettered “U. S. $\square$ B. M." (C. \& G. S. Q-3) -

Hillsboro, on front of first two-story brick store building west of Robinson Block (separated from it at present by a shed 15 feet wide), 12 inches from northwest corner and about 4 feet from ground, in center of eleventh brick above iron doorsill; copper bolt, lettered “ U. S. $\oplus$ B. M." (C. \& G. S. R-3) -

Feet.

598. 276

601.026

\section{U. S. Corps of Engineers bench marks along Tennessee River.}

Lock B, Elk River Canal, on south wall and outer corner of coping at recess for lower gate, 8 inches from either face of masonry; copper bolt, lettered "U. S. $\odot$ P. B. M." (U. S. Corps of Engineers p. b. m. 39)

Lock A, Elk River Canal, on south wall and outer corner of coping at recess for lower gate, 10 inches from either face of masonry; copper bolt, lettered "U. S. $\odot$ P. B. M." (U. S. Corps of Engineers p. b. m. 40 )

Lock A, Elk River Canal, on south wall, east end, and about 10 inches from north edge of masonry; highest point in square cut in coping (U. S. Corps of Engineers t. b. m. 141)

Elk River Canal, 690 feet east of Lock A, 38 feet south from shore of canal, in exposed ledge of rock $2 \frac{1}{2}$ feet above ground and 1 foot from edge of ledge; copper bolt, lettered "U. S. $\odot$ P. B. M." (U. S. Corps of Engineers p. b. m. 41)

Lock A, 1,690 feet above, at head of Elk River Canal, on east wall of waste weir, 6 inches from south edge of stone, and 7 inches east of timbering; copper bolt, lettered "U S. $\odot$ P. B. M." (U. S. Corps of Engineers p. b. m. 42)

Lock A, 1,440 feet above, Elk River Canal, on top of dam or canal wall; highest point of square cut on big rock (U. S. Corps of Engineers t. b. m. 142)

Miltons Bluff, on gage pier of canal wall or dam opposite, 1.2 miles above lock $A$, on south side, $2 \frac{1}{2}$ feet above top of wall of dam, in top of large center stone; copper bolt, lettered "U. S. $\odot$ P. B. M." (U. S. Corps of Engineers p. b. m. 43)

Miltons Bluff, on south shore of canal, 5 feet from water and a shopt distance east of old derrick, on large flat rock; highest point in square (U. S. Corps of Engineers t. b. m. 143)

Miltons Bluff, 1.2 miles above, in strip of brush between two small cornfields, about 200 feet south of river bank, on large oak tree; highest point in square cut (U. S. Corps of Engineers t. b. m. 146) --

Robinsons Landing, 0.5 mile below, midway between Miltons Bluff and Browns Ferry, 590 feet below end of Robinson's field, in woods on top of bank by side of path, 9 feet from two blazed elms, on a stone monument, marked "U. S.," set in summer of 1892 in connection with surface made to examine the South Channel; copper bolt at center of cross on stone ( U. S. Corps of Engineers p. b. m. 44)

Browns Ferry, 700 feet below, 180 feet below point where road turns away from river, north edge of wagon road, on top of river bank,
529.777

539.953

536.856

538. 424

535. 896

537. 393

535,958

539. 157

540. 491
538. 423 
on stone post marked "U. S.," set in connection with survey of 1892, standing 4 inches above ground; copper bolt at center of cross on stone (U. S. Corps of Engineers p. b. m. 45)

Browns Ferry, 530 feet below, at point where road turns away from river, 18 feet north of center of wagon road, at top of river bank, on stone post marked “U. S.," set in 1892, standing 3 inches above ground; top of spike leaded vertically (U. S. Corps of Engineers p. b. m. 46)

Findleys Landing, 440 feet below, in face of large rock just above path, and 20 inches above surface of ground; copper bolt, lettered "U. S. $\odot$ P. B. M." (U. S. Corps of Engineers p. b. m. 47) -

Feet. 545. 460

\section{TOWN CREEK QUADRANGLE.}

\section{Courtland west along Southern Ry. to Town Creek.}

Courtland, on front of two-story brick building owned and occupied by Merchants' Bank of Courtland, on east side of square, adjoining right of way of Southern Ry., in fifteenth brick above iron doorsill, two brick lengths north of southwest corner; copper bolt, lettered “U. S. $\oplus$ B. M." (C. \& G. S. S-3)

Courtland, at northeast corner of central square of village, in stone horse-block, a hard limestone rock with two steps cut in the east side, rising 3 feet above ground and said to extend 3 feet below surface of ground and to have been set about 75 years ago; in south side, 12 inches below top and 7 inches from west edge; copper bolt, lettered “U. S. $\oplus$ B. M.” (C. \& G. S. T-3)

Courtland, 0.5 mile west of, on right of way of Southern Ry., on hard limestone rock in place on west bank of Big Nance Creek, 27 feet south of center of railway track, on line perpendicular to track at point about 3 feet east of west abutment of trestle 383.5 ; a large bowlder is between bench mark and creek, separated from the rock on which mark was placed by a fissure about 8 inches wide; a sycamore tree about 2 feet in diameter with old blaze on north side is about 14 feet south, and a cedar tree 8 inches in diameter is 10 feet west of bench mark; bottom of square hole cut in stone, lettered “U. S. $\square$ B. M." (C. \& G. S. U-3)

Town Creek, 3 miles west of, on north end of east abutment of iron bridge of Southern Ry. across Town Creek, on top of abutment, 8 inches from shore face and 10 inches from downstream end, 11 inches diagonally from bridge seat; bottom of square hole in stone, lettered “U. S. $\square$ B. M." (C. \& G. S. V-3)

567.538

566.471

545.848

\section{ROGERSVILLE QUADRANGLE.}

\section{U. S. Corps of Engineers bench marks along Tennessee River.}

Lock 6, Muscle Shoals Canal, south side, west end, on fourth step below coping; highest point in square cut on stone (U. S. Corps of Engineers t. b. m. 107)

Lock 6, Muscle Shoals Canal, on river side, at west heelpost, between the A straps, about 6 inches from iron shoe; top of copper bolt, lettered “U. S. $\odot$ P. B. M." (U. S. Corps of Engineers p. b. m. 23) Lock 6, 3,080 feet east of, about 10 feet east from telegraph pole 4, at edge of bank, 10 feet south from center of track on a large rock; highest point in square (U. S. Corps of Engineers t. b. m. 108) ---- 
Sixmile Creek, at railroad bridge on Muscle Shoals Canal, on west abutment, north side; copper bolt, lettered "U. S. $\odot$ P. B. M." (U. S. Corps of Engineers p. b. m. 24)

Lock 6, 1.2 miles above, 100 feet east of section posts 22 and 23,8 feet south of center of track and 2.5 feet north of telegraph pole; highest point in square on embedded rock (U. S. Corps of Engineers t. b. m. 109)

Locks 5 and 6, between, Muscle Shoals Canal, at railroad bridge over Fourmile Branch, on south end of west abutment, on second step from top, 5 inches south of south edge of coping and 6 inches west of east edge of abutment; copper bolt, lettered "U. S. $\odot$ P. B. M." (U. S. Corps of Engineers p. b. m. 25)

Lock 5, Muscle Shoals Canal, on coping at south side and west end; highest point in square (U. S. Corps of Engineers t. b. m. 113)

Lock 5, Muscle Shoals Canal, on south wall, on outer corner of coping at recess of west gate, 10 inches from either face of masonry; copper bolt, lettered "U. S. $\odot$ P. B. M." (U. S. Corps of Engineers p. b. m. 26)

Lock 5, $800^{\prime}$ feet above (Muscle Shoals Canal, on west abutment of railroad bridge over Douglas Branch, on coping at south end, 8 inches from either face; copper bolt, lettered "U. S. $\odot$ P. B. M" (U. S. Corps of Engineers p. b. m. 27)

Lock 5, 3,200 feet east of, on line of Muscle Shoals Canal, west of section posts 14-15, between telegraph poles 7 and 8,12 feet south from center of track; highest point of square on rock (U. S. Corps of Engineers t. b. m. 114)

Lock 4, 260 feet below, Muscle Shoals Canal, on north end of east abutment of railroad bridge, in northwest corner of stone, 9 inches from either face; copper bolt, lettered "U. S. $\odot$ P. B. M." (U. S. Corps of Engineers p. b. m. 28)

Lock 4, Muscle Shoals Canal, on east end of south wall, near heelpost; highest point of square cut in coping stone (U. S. Corps of Engineers t. b. m. 116)

Lock 4, Muscle Shoals Canal, on south wall and outer corner of coping stone at recess for west gate, 10 inches from either face of masonry ; copper bolt, lettered "U. S. $\odot$ P. B. M." (U. S. Corps of Engineers p. b. m. 29)

Blue Water Creek, on north end of west abutment of bridge across on Muscle Shoals Canal, 5.5 inches west from edge of abutment and $4 \frac{1}{2}$ inches south from cap corner stone; copper bolt, lettered “U. S. $\odot$ P. B. M.” (U. s. Corps of Engineers p. b. m. 30)

Lock 3, Muscle Shoals Canal, on south wall, east end, near the A strap; highest point in square cut on coping (U. S. Corps of Engineers t. b. m. 118)

Lock 3, Muscle Shoals Canal, on south wall and outer corner of coping at recess for west gate, 10 inches from either face of masonry; copper bolt, lettered "U. S. $\odot$ P. B. M." (U. S. Corps of Engineers p. b. m. 31)

Lock 3, 3,760 feet east of, 18 feet east of telegraph pole 4, west from section post 7-8, 6 feet south of center of track; highest point in square cut on stone (U. S. Corps of Engineers t. b. m. 119)

Lock 2, 2,530 feet west of, 110 feet east of telegraph pole 11 (the second pole east of section posts 6-7) ; 6 feet south of center of track; highest point in square cut on rock (U. S. Corps of Engineers t. b. m. 120) 
Lock 2, Muscle Shoals Canal, on south wall, south of east gate; highest point in square cut in coping (U. S. Corps of Engineers t. b. m. 121)

Lock 2, Muscle Shoals Canal, on south wall and outer corner of coping at recess for west gate, 10 inches from either face of masonry; copper bolt, lettered “U. S. ๑ P. B. M." (U. S. Corps of Engineers p. b. m. 32)

Lock 2, 1,600 feet east of, Muscle Shoals Canal, on east abutment of railroad bridge over Second Creek, south end, in bridge-set stone, 6 inches east of west face and 30 inches north of south face of abutment; copper bolt, lettered “U. S. $\odot$ P. B. M." (U. S. Corps of Engineers p. b. m. 33)

Lock 1, Muscle Shoals Canal, on south side, at east end of surface wall above upper gate, just below wing wall; highest point in square (U. S. Corps of Engineers t. b. m. 125)

Lock 1, Muscle Shoals Canal, on south wall and outer corner of coping stone at recess for west gate, 10 inches from either face of masonry; copper bolt, lettered "U. S. ○ P. B. M." (U. S. Corps of Engineers p. b. m. 34)

Muscle Shoals Canal, at upper end of, on south side, on old dump, between section post 1 and telegraph pole 1 , 12 feet south of track center; highest point of square on rock (U. S. Corps of Engineers t. b. m. 126)

Muscle Shoals Canal, 1.6 miles above head of, 1.5 miles below Lambs Ferry, 50 feet from river bank, about 900 feet below upper end of corn field; spike in root of elm tree (U. S. Corps of Engineers t. b. m. 128)

Sycamore Landing, on north bank of Tennessee River, 78 feet above dripping spring and 154 feet in direct line from top of bank beside road to ferry, 25 feet below a pin oak tree $2 \frac{1}{2}$ feet in diameter, in a very prominently exposed ledge 9 inches above ground, on shelf of rock; an arrow cut on vertical front face of rock just above points to bench; copper bolt, lettered "U. S. $\odot$ P. B. M." (U. S. Corps of Engineers p. b. m. 35)

Feet. 511. 468

511. 476

513. 429

521. 356

521. 378

521. 095

514. 841

525. 658

Sycamore Landing, a short distance above, where wagon road comes within 24 feet of face of bluff, 95 feet from top of river bank, 30 feet below prominent point of rock, at angle of ledge, 10 feet upstream from large overhanging oak tree growing on top of ledge; an arrow cut into face of rock points toward bench; copper bolt, lettered “U. S. ๑ P. B. M.” (U. S. Corps of Engineers p. b. m. 36) -

Lock B, Elk River Canal, 1 mile below, 25 feet from shore line and 26 feet east of fence meeting bluff, in face of rock bluff; copper bolt, lettered "U. S. $\odot$ P. B. M." (U. S. Corps of Engineers p. b. m. 37)

Lock B, 0.8 mile below, Elk River Canal, in face of rock bluff above root of uprooted linn tree that leans against bluff, 65 feet above path, 16 inches above ground; copper bolt, lettered "U. S. $\odot$ P. B. M." (U. S. Corps of Engineers p. b. m. 38)

Lock B, Elk River Canal, on north side, eəst gate, between A straps; highest point in square cut in coping (U. S. Corps of Engineers t. b. m. 140)

528.982

536. 036 . 


\section{TUSCUMBIA QUADRANGLE.}

Pride along Southern Ry, to Tuscumbia.

Pride, 4 miles east of, at west end of railroad bridge over Little Bear Creek, on west end of abutment, 460 feet west of milepost 142; highest point in square cut on stone (U. S. Corps of Engineers t. b. m. 71)

Tuscumbia, at west part of town, at east end of railroad bridge over Spring Creek, on north end of coping stone of abutment, 3 feet below top of ties; highest point in square (U. S. Corps of Engineers t. b. m. 79)

Tuscumbia, on end of curbstone at northwest end of Parshal Hotel; highest point in square (U. S. Corps of Engineers t. b. m. 80)-----

Tuscumbia, in southwest corner of county courthouse water table $6 \frac{1}{2}$ inches east of corner; center punch mark of copper bolt (U. S. Corps of Enginéers p. b. m. 8)

Tuscumbia, on east side of Main Street, $16 \frac{1}{2}$ feet south of Fifth Street, on stone base of Wilson's bank building; copper bolt, lettered "U. S. $\odot$ P. B. M." (U. S. Corps of Engineers p. b. m. 9) --

Feet. 452. 808

450.254

468. 397

480.160

469. 760

Leighton west along Southern Ry. to Tuscumbia.

Leighton, in brick wall of store building known as King Building, now occupied by King \& Co., 16 inches from northwest corner, in seventeenth brick from brick sidewalk; copper bolt, lettered "U. S. $\oplus$ B. M." (C. \& G. S. W-3)

Tuscumbia, 4 miles east of, on right of way of Southern Ry., 33 feet north of track, 2 feet from railway fence, about 300 yards west of west switch stand at Hobgood siding of Southern Ry., in top of stone post 5 feet long, with 1 foot projecting, octagonal in shape, and about 8 inches in diameter; bottom of square hole, lettered “U. S. 口 B. M." (C. \& G. S. X-3)

\section{FLORENCE QUADRANGLE.}

\section{J. S. Corps of Engineers bench marks along Tennessee River.}

Florence, opposite, on east end of south abutment of railroad bridge over Tennessee River at about the elevation of top of ties; highest point in square cut in coping (U. S. Corps of Engineers t. b. m. 86) -

Florence, on south side of Tennessee River opposite, on lower or wagon-way abutment of railroad bridge, in east end of bridge seat stone, 5 inches from its east end and $4 \frac{1}{2}$ inches back from its front face; top of copper bolt, lettered "U. S. $\odot$ P. B. M." (U. S. Corps of Engineers p. b. m. 10)

Florence, on north end of railroad bridge over Tennessee River, on east end of stone abutment, at about the elevation of top of ties; highest point in square marked "U. S." (U. S. Corps of Engineers t. b. m. 87)

Florence, at north end of bridge across Tennessee River, on second pier north of wagon road, on west side of bent, on pedestal stone, 7 inches from its west edge and 6 inches from its north edge; highest point of square in southwest part of cross, marked "U. S. +B. M." (U. S. Corps of Engineers " Old gage B. M.”) --_-_-_--
510.939

572.447

463. 686

441. 429

450.500 
Florence, upon draw pier of railroad bridge across Tennessee River, 9 feet north of pivot, 28 inches north of up-river side of span when closed and 6 inches outside of rack; copper bolt, lettered "U. S. $\odot$ P. B. M." (U. S. Corps of Engineers p. b. m. 11)

Florence, on north side of Tennessee River, second pier north of north abutment of Florence bridge, on east pedestal stone, near its northwest corner; copper bolt, lettered "U. S. $\odot$ P. B. M." (U. S. Corps of Engineers p. b. m. 12)

Feet.

431. 736

Florence, on line of Louisville \& Nashville R. R., on right bank of river, about 300 feet below northwest corner of lock factory, 16 feet south of track center, one-half foot above top of ties; highest point in square cut in ledge of rock (U. S. Corps of Engineers t. b. m. 90)

Florence, in Louisville \& Nashville R. R. yards, 374 feet below northwest corner of lock factory and 203 feet east of small trestle, 39 feet from top of high river bank, 12 feet north of center of south track, and 2 feet above top of ties, in very large blue limestone; copper bolt, marked "U. S. P. B. M."; an arrow is also cut on stone, pointing to bolt (U. S. Corps of Engineers p. b. m. 13) --

East Florence, in old bucket factory now occupied by Eureka Lumber Co., on inside face of north wall, in first pier east of first arch about 4 feet above ground, in center stone; copper bolt, lettered “U. S. $\odot$ P. B. M." (U. S. Corps of Engineers p. b. m. 14) --

East Florence, 1.2 miles above, at foot of hill opposite end of old railroad, 32 feet east of ravine and $\mathbf{1 1 5}$ feet north of river bank, on ledge of rock in place; highest point in square cut (U. S. Corps of Engineers t. b. m. 93)

East Florence, 1.2 miles above, 215 feet east of ravine, at end of abandoned railroad, about 183 feet above temporary bench mark 93 , about 650 feet east from dam on opposite side of river, in vertical ledge of rock; copper bolt, lettered "U. S. $\odot$ P. B. M." (U. S. Corps of Engineers p. b. m. 15)

East Florence 2.2 miles above, 0.2 mile below mouth of Fourmile Creek, 28 feet west of Dunnehue Falling Spring, and about 9 feet in elevation above path under overhanging rock inside of wall where there was once a camp; copper bolt, lettered "U. S. $\odot$ P. B. M." (U. S. Corps of Engineers p. b. m. 16)

Bainbridge, 1.2 miles below, 1,870 feet below lower end of field, a short distance below very large rock in river about 20 feet from shore, in a large rectangular bowlder sloping toward the river and forming retaining wall for path, 10 feet toward river from path, about 2 feet from river edge of bowlder and 1 foot from upstream edge; copper bolt, lettered “U. S. $\odot$ P. B. M." (U. S. Corps of Engineers p. b. m. 17)

Bainbridge, 1 mile below, about 190 feet below lower end of field and 50 feet below wire fence running to river and 75 feet from river shore; highest point in square on a large rock fallen from bluff (U. S. Corps of Engineers t. b. m. 99)

456. 852

458. 820

472. 580

437.694

442. 989

437. 747

428. 847

430. 819

Bainbridge, 1,160 feet west of west end of lock 9, Muscle Shoals Canal, 18 feet north of Morrison's Spring, 4 feet west of small blacksmith shop, 37 feet north of center of present wagon road and $5 \frac{1}{2}$ feet above it, under overhanging rock; copper bolt, lettered “U. S. $\odot$ P. B. M.” (U. S. Corps of Engineers p. b. m. 18) 
Lock 9, Muscle Shoals Canal, on north side and west end; highest point in square cut in top of masonry (U. S. Corps of Engineers t. b. m. 102)

Lock 9, Muscle Shoals Canal, on river side of lock, at west heelpost, between the A straps, 7 inches from iron shoe; copper bolt, lettered “U. S. $\odot$ P. B. M." (U. S. Corps of Engineers p. b. m. 19)

Lock 8, Muscle Shoals Canal, on south side of lock, at its foot on south side of masonry; highest point in square marked "U. S. T. B. M." (U. S. Corps of Engineers t. b. m. 103)

Lock 8, Muscle Shoals Canal, on river side of lock, at west heelpost, between the A straps, 6 inches from iron shoe; copper bolt, lettered “U. S. $\odot$ P. B. M." (U. S. Corps of Engineers p. b. m. 20)

Lock 7, Muscle Shoals Canal, on south side and west end of lock, near southwest corner of stone forming third step from top; highest point in square (U. S. Corps of Engineers t. b. m. 104)

Lock 7, Muscle Shoals Canal, on river side of lock, at west heelpost, between the A straps, about 6 inches from iron shoe; copper bolt, lettered "U. S. $\odot$ P. B. M." (U. S. Corps of Engineers p. b. m. 21)

Lock 7, Muscle Shoals Canal, 1,445 feet east from foot of, 1 foot from west end and 15 inches from south edge of stone on south end of east abutment of railroad bridge over Shoal Creek; copper bolt, lettered “U. S. $\odot$ P. B. M." (U. S. Corps of Engineers p. b. m. 22)

Lock 7, Muscle Shoals Canal, 0.5 mile east of lock, 150 feet west of section posts 26 and 27 , on large rock, about 12 feet south of center of track; highest point in square cut in stone (U. S. Corps of Engineers t. b. m. 105)

Feet.

436. 287

436. 307

446. 366

446. 384

454.843

458. 342

457.845

459. 124

BARTON QUADRANGLE.

Pride west along Southern Ry, to Cherokee.

Pride, 2.7 miles west of, 48 feet north of center of Southern Ry. track, on line perpendicular to track at point about 9 feet east of trestle 416.4A (from Bristol), on large hard limestone rock in place, the southeast one of a number of similar rocks, in size about 4 by 9 feet and rising about 10 inches above ground at its highest part, 3 feet from south edge and 16 inches from west edge of rock; bottom of square hole, lettered “U. S. $\square$ B. M." (C. \& G. S. Y-3) -

Cherokee, 0.5 mile west of, in deep cut, 10 feet north of center of track, on face of stratum of sandstone, 2 feet above top of rails; copper bolt, lettered “U. S. $\oplus$ B. M.” (C. \& G. S. Z-3)

441.658

538. 350

Barton along Southern Ry. to Pride.

Barton, 0.8 mile west of station, 1,390 feet east of mile post 133, 15 feet south of center of track, on end of stone culvert; highest point in square (U. S. Corps of Engineers t. b. m. 58)

Barton, 354 feet west of station, 15 feet north of track center, on an embedded rock; highest point in square (U. S. Corps of Engineers t. b. m. 59)

Pride, 1.5 miles west of, 1,720 feet east of milepost 136, on south end of abutment of bridge over Bear River, on coping 3 feet below top of ties; highest point of square cut in stone (U. S. Corns of Engineers t. b. m. 63)

495. 503

482.548 
Pride, 2,130 feet toward the river from station, about 450 feet west of L. T. Pride's house, 30 feet east of large mulberry tree, on east edge of creek bed, on large ledge of rock washed by its water; highest point in square marked "U. S." (U. S. Corps of Engineers t. b. m. 72 )

Pride, 160 feet above mouth of creek that empties just above J. P. Pride's residence, 27 feet back from top edge of high bank on point of bluff, at cluster of bowlders on north face of large embedded bowlder, 14 inches above surface of ground; copper bolt (U. S. Corps of Engineers p. b. m. 7)

Pride, 20 feet northeast of permanent bench mark 7 , on very large bowlder; highest point of square cut in rock and lettered "T. B. M." in deeply-cut letters (U. S. Corps of Engineers t. b. m. 73)

Pride, 2.2 miles east of, 460 feet east of milepost 140 , in big cut, about 25 feet east of east end of long tangent through Cherokee and Pride, 15 feet south of center of track and $1 \frac{1}{2}$ feet above top of tie; highest point in square cut in ledge (U. S. Corps of Engineers t. b. m. 68)

Feet. 429. 346

422. 529

419.115

488.083

\section{IUKA QUADRANGLE.}

Margerum west along Southern Ry. to Riverton Junction.

Margerum, 1.25 miles east of, on west abutment of Southern Ry. deck plate girder of bridge 426.8A (from Bristol) over Buzzard Roost Creek, on lowest step of retaining wall, 13 feet north of center of track, $5 \frac{1}{2}$ feet below top of ties and 2 feet above top of abutment proper, 12 inches from north edge of stone and 11 inches from east edge; bottom of square hole, lettered "U. S. $\square$ B. M." (C. \& G. S. A-4)

Riverton Junction, 1.2 miles west of, on south end of west abutment of bridge over Big Bear Creek, on coping stone, 8 inches and 30 inches from south and west edges, respectively, 1 foot below top of pedestal stone, about 3 inches below top of ties, and about 10 feet from center of track; bottom of square hole, lettered "U. S.

B. M." (C. \& G. S. B-4)

Riverton Junction, 2 miles west of, on stone post marking State line between Alabama and Mississippi, 15 feet north of center of track; the post rises above ground about 4 feet and leans slightly westward, but appears to be set firmly in ground; bench mark is intersection of two lines cut on side of post toward railway track, marked "S $\frac{\mathrm{M} \mid \mathrm{A}}{\mathrm{A}}$ " (C. \& G. S. C-4)

\section{Riverton to Indian Creek.}

Riverton, in extreme western part of town, about 0.5 mile below station, 27 feet from river bank and $1 \frac{1}{2}$ feet east of farm fence running to river, in stone post 4 feet long standing 6 inches above top of ground; copper bolt, lettered "U. S. $\odot$ P. B. M." (U. S. Corps of Engineers p. b. m. 4)

Riverton, 0.8 mile above, 1,200 feet south of lift lock, Colbert Shoals Canal, in cultivated field on conspicuous Indian mound; highest point of limestone post set in ground (U. S. Corps of Engineers p. b. m. 5; equals old gage bench mark)
${ }^{a} 414.803$

433. 314

440.082

(1)


Lift Lock, Colbert Shoals Canal, 0.5 mile above, in limestone post marking south corner of United States building reservation, opposite station 33 of canal, 10 feet north of highway and 13 feet south of road fence; copper bolt in northeast corner of post (U. S. Corps of Engineers p. b. m. 6)

Feet.

Riverton, 2 miles below, 0.3 mile below Big Bear River, directly back from Eastport Landing, in creek bed at foot of bluff, 130 feet up creek from fence, on east side of creek bed, 2.9 feet back from top edge of long, unbroken step of rock of 9 inches rise extending clear across creek, in broken angle formed by next step, which is worn through in middle where water runs over it; $5 \frac{1}{2}$ inches north of one part of this second step and $7 \frac{1}{2}$ inches west of other part of

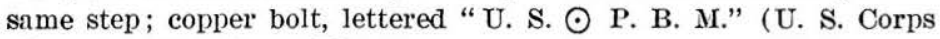
of Engineers p. b. m. 53)

Big Bear River, 2.8 miles below, on property of Joe Payne, a short distance below Payne's Landing, in woods on slope, at foot of bluff, about 40 feet east of beech tree standing on top of bluff and 60 feet north of hickory tree, in first ledge of rock below Payne's Landing, 14 inches abore ground; center of punch mark in copper bolt, lettered “U. S. $\odot$ P. B. M.” (U. S. Corps of Engineers p. b. m. 54) --

Indian Creek, 1 mile above, on land of R. W. Busbee, at foot of bluff, 50 feet from fence, 20 feet back from black walnut tree 15 inches in diameter, and 20 feet from hickory tree deeply blazed toward the bench, on rounding ledge east of creek, $2 \frac{1}{2}$ feet above ground, just below and 5 inches from first rertical shelf; copper bolt, lettered “U. S. $\odot$ P. B. M.” (U. S. Corps of Engineers p. b. m. 55) -

404. 793

398. 773

Pegram along Southern Ry, to Barton.

Margerum, on footing course of masonry, at southwest corner of water tank at north edge of track; highest point in square (U. S. Corps of Engineers t. b. m. 45)

${ }^{a} 436.864$

Margerum, 1.2 miles east of, 410 feet west of milepost 125 (from Memphis), on west abutment of railroad bridge over Buzzard Roost Creek, at its southeast corner; highest point of square cut in stone (U. S. Corps of Engineers t. b. m. 47)

Cherokee, 2.2 miles west of, 2,190 feet west of milepost $12 \pi$, on big fill, 10 feet south of center of track, 3 feet below top of tie, on large embedded rock; highest point in square (U. S. Corps of Engineers t. b. m. 49)

414. 810

\section{CULLMAN $30^{\prime}$ QUADRANGLE.}

Hartsells along Louisville \& Nashville R. R. to Garden City.

Hartsells, 0.2 mile south of, in west side of arched stone culvert, 5 inches from west edge of third stone from south end; copper bolt, lettered "U. S. $\ominus$ B. M." (C. \& G. S. W-2)

Hartsells, 3 miles south of, 0.8 mile north of Leesdale, on north abutment of trestle 10, on northeast corner of east stone supporting the trestlework ; bottom of square hole (C. \& G. S. t. b. m. 60) _-_-

Falkville, 1 mile south of, 3 paces south of milepost " D-20-M Y-163, $2 / 327$," 12 feet west of west rail of main track of Louisville \& Nashville R. R.; square cut on top surface of rock in place, lettered “U. S. $\square$ B. M." (C. \& G. S. X-2) 
Vilhite, 1.5 miles south of, in west bridge-seat stone of south abutment of trestle 19, $3 \frac{1}{2}$ inches from north edge and $2 \frac{1}{2}$ inches from west edge of stone; copper bolt (C. \& G. S. Y-2)

ullman, 3.5 miles north of, about 20 rails south of milepost 30 (from Decatur), along the Louisville \& Nashville R. R,; in top surface of north stone of east side of culvert, $4 \frac{1}{2}$ inches from east edge and 30 inches from north edge of stone; copper bolt (C. \& G. S. Z-2) -ullman, in stone block supporting northeastern one of four inner columns of railway water tank, $2 \frac{1}{2}$ inches from north and 4 inches from east edge of stone; copper bolt (C. \& G. S. A-3)

ohnson, 200 yards north of railroad sign, 4 rails south of milepost 40 (from Decatur), along line of Louisville \& Nashville R. R., on east side of south abutment of trestle 33 , in top surface of second course of masonry from top, 6 inches from east and north edges of stone; copper bolt (C. \& G. S. B-3) anceville, 3 miles south of, 0.25 mile south of milepost 44 (from Decatur), on west side of stone culvert, in second stone from north end, 4 inches from west edge and 7 inches from north edge of stone; copper bolt (C. \& G. S. C-3)

arden City, 1 mile south of, on mid-river pier of trestle 36 , over Mulberry Branch of Black Warrior River, in a triangular-shaped stone, on top of east side of pier, 6 inches from each side and 8 inches from outer point of stone; copper bolt (C. \& G. S. D-3) ----

Feet.

675. 129

857.514

\$02. 672

650.451

530.509

BIRMINGHAM 30' QUADRANGLE.

\section{Blount Springs south along Louisville \& Nashville R. R. to Birmingham.}

ount Springs, 0.8 mile north of, in top stone on east side of north abutment of bridge 38,13 inches from east edge and 16 inches from north edge of stone; copper bolt (C. \& G. S. E-3)

lount Springs, 0.8 mile south of, on east side of south bridge-seat stone of trestle 41 , in top surface of large stone, 6 inches from east and 8 inches from north side of stone; copper bolt (C. \& G. S. F-3)

teids, 200 yards south of, 100 feet south of milepost 58 (from Decatur), on west side of south part of an arched stone culvert, in first stone of downstream revetment, below top course of masonry, 3 inches from west and $3 \frac{1}{2}$ inches from north edge of stone; copper bolt (C. \& G. S. G-3)

Warrior, just within right of way of Louisville \& Nashville R. R., 15 paces west of siding, 75 feet north of station, across tracks, 4 feet from boundary fence, 4 paces south of a 14-inch oak, back of railroad toolhouse; bottom of square hole in top of limestone post 30 inches long, lettered “U. S. $\square$ B. M.” (C. \& G. S. H-3)

455. 262

Warrior, 2 miles south of, on long trestle, No. 45, over Locust Branch of Black Warrior Rirer, in stone under bridge-seat stone, on east side of south abutment, 6 inches from east and 8 inches from north edge of stone; copper bolt (C. \& G. S. I-3)

Morris, 20 paces west of siding and 60 feet north of station, $2 \frac{1}{2}$ feet from fence running east-west, 7 paces west of corner of fence at intersection of railroad right of way line and county road; bottom of square hole in top of limestone post 30 inches long, lettered “U. S. $\square$ B. M.” (C. \& G. S. J-3)

426. 879

407. 634

588. 215

547. 710

412.665 
Cunningham, 2 miles north of, on east side of south abutment of trestle 50, on bridge-seat stone, 2 inches from east and 8 inches from south edge of stone; bottom of square hole (C. \& G. S. t. b. m. $10 \overline{7}$ )

Newcastle, 30 paces east of main track of Louisville \& Nashville R. R., 15 paces south of station, about on a level with railroad grade, but on side of hill near a small group of trees; bottom of square hole in top of stone post 30 inches long, lettered "U. S. B. M." (C. \& G. S. K-3)

Boyles, 30 paces south of station, 25 paces west of tracks, 4 paces north of large 14-inch tree; bottom of square.hole in top of stone post 30 inches long, lettered “U. S. $\square$ B. M." (C. \& G. S. L-3) ----

Feet. 395. 937

584. 32

Birmingham along Alabama Great Southern R. R. to Elyton.

Birmingham, in southeast corner of west wing of courthouse, 10 inches from east corner, second course above base stone; copper bolt, lettered “U. S. $\odot$ P. B. M." (U. S. Corps of Engineers p. b. m. 1)

Birmingham, at west side of Third Avenue entrance to courthonse, on base stone of fence, behind stone post; highest point in square (U. S. Corps of Engineers t. b. m. 1)

Birmingham, northeast corner of First Avenue and Nineteenth Street, about 72 feet north of First Arenue, on base stone under sixth pillar of L. Sak's store, on south end of stone; copper bolt, lettered “U. S. $\odot$ P. B. M." (U. S. Corps of Engineers p. b. m. 2) -

Birmingham, in north side of west entrance to customhouse, on third step from top, between pillar of arch and pilaster; copper bolt, lettered “U. S. $\odot$ P. B. M." (U S. Corps of Engineers p. b. m. 3)

Birmingham, on north side of dummy car track, about 3,600 feet below post office or customhouse, on Elerenth Street, in front of store, 10 feet west of end of curbing at waterway; square cut on curbing (U. S. Corps of Engineers t. b. m. 2)

Elyton, 325 feet east of section house 160, on northeast corner of stone culvert, 18 inches from edge of timber; highest point in square (U. S. Corps of Engineers t. b. m. 3)

BESSEMER QUADRANGLE.

West End along Alabama Great Southern R. R. to Jonesboro.

West End, 1.5 miles west of, on line of Alabama Great Southern R. R., 328 feet east of road crossing, in center of south end of southeast abutment of top stone; highest point in square (U. S. Corps of Engineers t. b. m. 7)

Powderly, 1.5 miles abore, 470 feet below center of road crossing, 29 feet south of center of track, in very large bowlder forming north bank of ditch; copper bolt, lettered "U. S. P. B. M." (U. S. Corps of Engineers p. b. m. 4)

Powderly, 100 feet below crossing of Alabama Great Southern R. R. and dummy line, 50 feet south from center of track, on upper part of large ridge of rock; highest point in square (U. S. Corps of Engineers t. b. m. 8)

Milepost 146 (from Meridian), 66 feet below, 13 feet north of center of track; highest point in square cut on bowlder (U. S. Corps of Engineers t. b. m. 9)
$610.35 \AA$

606. 300

571.048

544. 626 
Hillman, 1.5 miles east of, 100 feet below bridge 84,26 feet north of track, highest point in square on stone ledge (U. S. Corps of Engineers t. b. m. 10)

Hillman, 250 feet above, at north side of bridge 85 , on very large rock in bed of Downeys Creek; highest point in chiseled square (U. S. Corps of Engineers t. b. m. 11)

Turpin, about equidistant from crane, post office, and crossing of roald to mines, on northeast abutment of viaduct, on second step from top, 5 inches from first step; highest point in square (U. S. Corps of Engineers t. b. m. 13)

Ressemer, 1,300 feet east of brickyard, 39 feet north of center of track, 14 feet in front of 12-inch sweet-gum tree, on center of rock in place dipping north; highest point in square (U. S. Corps of Engineers t. b. m. 14)

Feet. 521. 681

512.549

Bessemer, 300 feet above crossing of Alabama Great Southern R. R. and Louisville \&'Nashville R. R. tracks, on southeast corner of stone culvert; highest point in square (U. S. Corps of Engineers t. b. m. 15)

Bessemer, on southeast corner of Nineteenth Street and Fourth Avenue, at main (corner) entrance of brick building with stone trimmings, occupied by the Bessemer Loan \& Improrement Co., in east end of top stone; copper bolt, lettered "U. S. $\odot$ P. B. M." (U. S. Corps of Engineers p. b. m. 5)

Jonesboro, at north side of track, in base stone of southeast corner of water tank; highest point in square (U. S, Corps of Engineers t. b. m. 18)

BROOKWOOD 30' QUADRANGLE.

McCalla along Alabama Great Southern R. R. to Cottondale.

McCalla, 0.8 mile below, about 1,700 feet below bridge 87 , on southeast corner stone of open culvert; highest point in square (U. S. Corps of Engineers t. b. m. 24)

Baylor, 0.2 mile above, 490 feet north of milepost 131 from Meridian, on northwest corner of culvert, on third step from bottom; highest point in square cut on stone (U. S. Corps of Engineers t. b. m. 27) --

Kimbrell, 57 feet west from center of track, at point 550 feet above upper fence at crossing, on very large ridge of limestone rock, 50 feet above pyramidal point at lower end of rock and $8 \frac{1}{2}$ feet from cedar tree 4 inches in diameter; copper bolt, lettered "U. S. $\odot$ P. B. M." (U. S. Corps of Engineers p. b. m. 6)

491.050

Tannehill, about 1.2 miles south of, 0.5 mile above Standiford, 656 feet south of milepost 127 from Meridian, at southeast corner of bridge 94 ; highest point in square cut in stone (U. S. Corps of Engineers t. b. m. 32)

Woodstock, 0.8 mile below, 334 feet south of milepost 122 from Meridian, on southwest corner of culvert, 2 feet from end of stone; highest point in square (U. S. Corps of Engineers t. b. m. 39)

Bibbville, 0.8 mile below, on south side of track, opposite milepost 120 from Meridian; highest point in square cut in stone (U. S. Corps of Engineers t. b. m. 42)

Vance, 0.5 mile above, 1,312 feet south of milepost 118 from Meridian, 328 feet south of old ginhouse, on north end of culvert marked "1888," upper side, on first step below coping; copper bolt, lettered “U. S. $\odot$ P. B. M.” (U. S. Corps of Engineers p. b. m. 7) - 
Vance, 0.8 mile below, about 2,950 feet below milepost 117 from Meridian, on northwest corner of small culvert, on second step from top; highest point in square (U. S. CorIs of Engineers t. b. m. 47)

Coaling, 795 feet below station, on south end of culvert, under Alabama Great Southern R. R. track, on west side, third step from top, on corner of stone 11 inches north of south end and 11 inches from east face; copper bolt, lettered "U. S. $\odot$ P. B. M." (U. S. Corps of Engineers p. b. m. 8)

Johnson, 50 feet abore lower end of rock cut below, on shelf of rock on south side of track, and of same elevation as top of rail, 20 feet below old fence on opposite side of track; an arrow is cut below pointing up to bench; highest point in square (U. S. Corps of Engineers t. b. m. 60)

Cottondale, 1,640 feet above station, on north end of large stone culvert, on west end of coping stone, 2 feet east of west edge and 6 inches from north face; copper bolt, lettered "U. S. P. B. M. $\odot$ " (U. S. Corps of Engineers p. b. m. 9)

Cottondale, 2 miles below, 740 feet below milepost 102 frọm Meridian, on west side of track, at southwest corner of small stone culvert; highest point in square cut in stone (U. S. Corps of Engineers t. b. m. 69)

Feet. 471. 8

371.58

324. 78

245.47

350.09

TUSCALOOSA QUADRANGLE.

Cottondale along Alabama Great Southern R. R. to Hull.

Cottondale, 2.6 miles below, 1,280 feet above milepost 101 from Meridian, on northwest corner of small open culvert; highest point in square (U. S. Corps of Engineers t. b. m. 70)

Tuscaloosa, 1.6 miles above station, 0.2 mile above milepost 98 from Meridian, on south end of large stone eulvert, on east end of coping stone; highest point in square (U. S. Corps of Engineers t. b. m. 75) _

Tuscaloosa, southwest corner of Market and Cotton streets, on stone base under window sill of city hall, 19.7 feet south of main entrance; copper bolt, lettered "U. S. $\odot$ P. B. M." (U. S. Corps of Engineers p. b. m. 11)

Lock 1, on land corner stone nearest head of steps leading down to lock walls, sontheast quarter of cross on surface (U. S. Corps of Engineers " Old B. M. 3 ")

Tuscaloosa, at Lock 1, Warrior River Canal, on south wall of lock, east end, 9 inches from edge of wall, just above recess for gate; copper bolt, lettered "U. S. $\odot$ P. B. M." (U. S. Corps of Engineers p. b. m. 12)

Lock 1, on face angle of coping at southeast quoin; small circle cut inside square (U. S. Corps of Engineers p. b. m. "Old B. M. 4 ") --

Tuscaloosa, south pier of county bridge, on projection of foundation course; top of iron bolt leaded vertically (U. S. Corps of Engineers b. m. "Old B. M. 5 ")

Tuscaloosa, about 980 feet below pier of new Mobile \& Obio R. R. bridge at west side of inclined gage, under 43-foot mark, on stone monument set in ground; copper bolt, lettered "U. S. $\odot$ P. B. M." (U. S. Corps of Engineers p. b. m. 13)

361.41

214. 01

222. 67

146. 72

112. 461

112. 440

92. 002

126. 555 
Tuscaloosa, 1,145 meters below Alabama Great Southern station, north end of stone culvert, on second step below coping, 6 inches from first step and 8 inches from face of second step; top of copper bolt, lettered “U. S. P. $\odot$ B. M." (U. S. Corps of Engineers p. b. m. 10)

Tuscaloosa, 0.6 mile below station, 460 feet below milepost 96 from Meridian, on east end of brick culvert; highest point in square cut on brick (U. S. Corps of Engineers t. b. m. 78)

Fuscaloosa, 2.5 miles below, 740 feet below road crossing and 295 feet above mileposi 94 from Meridian, on west end of stone culvert and south end of coping; highest point in square (U. S. Corps of Engineers t. b. m. 80)

Englewood, 180 feet above lower end of switch, on cement top of east end of iron culvert pipe; highest point in square (U. S. Corps of Engineers t. b. m. 88)

Hull, 100 feet south of station, on west end of culvert, on top of first brick north of center joint over iron pipe; highest point in square (U. S. Corps of Engineers t. b. m. 94)

Hull, 63 feet above north end of station and 10 feet east of corner of track, on brick culvert, 1 foot from north face and 6 inches from end ; copper bolt lettered “U. S. $\odot$ P. B. M." (U. S. Corps of Engineers p. b. m. 14)

Feet.

166. 813

169. 608

137. 792

138. 417

128.496

129. 390

POWERS QUADRANGLE.

Moundville along Alabama Great Southern R. R. to Akron.

Moundville, 164 feet below station, on foundation stone of water tank, on northwest corner of west one of two north pillars; highest point of square cut on stone (U. S. Corps of Engineers t. b. m. 100)

Moundville, about 170 feet south of station, in foundation stone of water tank, in northwest corner of southwest pedestal of center quadrilateral; copper bolt, lettered "U. S. $\odot$ P. B. M." (U. S. Corps of Engineers p. b. m. 15)

Powers, 656 feet above station, on east end of large stone culvert, on first step below coping, north side; copper bolt, lettered "U. S. $\odot$ P. B. M." (U. S. Corps of Engineers p. b. m. 16)

Akron, on west side of track, opposite north end of station, on brick culvert, on top of first brick south of center joint and 1 foot back from west end; highest point in square (U. S. Corps of Engineers p. b. m. 17)

163. 690

163. 726

136. 851

130. 194

EUTAW QUADRANGLE.

Akron along Alabama Great Southern R. R. to Hairston.

Warrior River, on south end of pier at east end of drawspan, on southwest corner of coping, 10 inches from west face and 8 inches from south face of coping; copper bolt, lettered "U. S. $\odot$ P. B. M." (U. S. Corps of Engineers p. b. m. 18)

Warrior River, 0.3 mile west of west end of trestle, on foundation stone of water tank, south side, on northeast pedestal of quadrilateral ; highest point in square (U. S. Corps of Engineers t. b. m. 122)- 
Eutaw, 2.1 miles above, 490 feet above milepost 64 from Meridian, on top of south end of brick culvert; highest point in square (U. S. Corps of Engineers t. b. m. 123)

Eutaw, 1.7 miles above, 3,150 feet above milepost 63 from Meridian, just above deep cut on south end of brick culvert; highest point in square cut on brick (U. S. Corps of Engineers t. b. m. 124)

Eutaw, 460 feet below north side of station, on coping of brick culrert, north side, 4 feet above south end, about 7 inches back from face; top of copper bolt, lettered “U. S. $\odot$ P. B. M." (U. S. Corlus of Engineers p. b. m. 19)

Eutaw, on Greensborough Street, in northwest corner of Palmer, Banks \& Co.'s store, in base stone under window sill, just off sidewalk; copper bolt lettered "U. S. $\odot$ P. B. M." (U. S. Corps of Engineers D. b. m. 20)

Feet.

117. 240

118. 301

174.100

Hairston, 2.2 miles above, 1,875 feet below milepost 5s, from Meridian, 572 feet above whistling post, on southwest quarter of stone culvert, on fourth step from bottom; highest point in square cut on stone ( U. S. Corps of Engineers t. b. m. 132)

Hairston, 1.2 miles below, 515 feet above milepost 54 from Meridian, on northwest quarter of stone culvert, on fourth step from bottom; highest point in square cut on stone (U. S. Corps of Engineers t. b. m. 138)

132. 308

EPES QUADRANGLE.

Boligee along Alabama Great Southern R. R. to Livingston.

Boligee, 1.2 miles above, 0.6 mile below milepost 54 from Meridian, on east end of stone culvert, north side, on second step below coping; highest point in square cut on stone (C. S. Corps of Engineers t. b. m. 139)

122. 655

Boligee, 1.2 miles above, on same culvert as temporary bench mark $139,3,345$ feet above section foreman's Louse, on east end of stone culvert, south slde, on second step from top, 10 inches from outer edge and 8 inches from face of stone; copper bolt, lettered " $\mathrm{C}$. S. $\odot$ P. B. M." (L. S. Corps of Engineers p. b. m. 21)

Miller, 1.4 miles below, 1.5 miles abore Enes, 960 feet above upper end of trestle east of Tombigbee River, at first curve in track above trestle, on top of railroad iron set as a post to mark point of curve; surface at southwest quarter of cross cut on iron (U. S. Corps of Engineers t. b. m. 150)

Epes, opposite, on east side of Tombigbee River, in east face of east pier of Alabama Great Southern R. R. bridge, in eleventh brick of tie course from south end of pier, and in fifty-eighth course of brick below first projecting course at top; copper bolt, lettered “U. S. $\odot$ P. B. M.” (U. S. Corps of Engineers p. b. m. 22) -__Epes, in south end of pier at east end of drawspan, in coping stone, 7 inches from south end and 28 inches from east face; copper bolt, lettered “U. S. $\odot$ P. B. M.” (U. S. Corns of Engineers p. b. m. 23) -

Epes, 40 feet west of station, on north end of brick culvert, in middle of sixth brick from west face; highest point in square cut on brick (U. S. Corps of Engineers t. b. m. 152)

Epes, 1 mile west of, 530 feet below road crossing, at lower end of cut on south end of tile culvert; highest point in square cut on pipe (U. S. Corps of Engineers t. b. m. 153) 
Parker, 0.5 mile east of, 850 feet below milepost 42 from Meridian, at upper end of long cut and tangent, at point of curve on south side of track, on surface in northeast quarter of cross; top of iron tangent post (U. S. Corps of Engineers t. b. m. 156)

Parker, 5i0 feet south of north switch stand, on southeast quarter of stone culvert; highest point in square cut in stone (U. S. Corps of Engineers t. b. m. 157)

Livingston, 3.2 miles above, 1,150 feet abore milepost 39 from Meridian, on southeast corner of brick culvert; highest point of square cut in brick (U. S. Corps of Engineers t. b. m. 160)

Livingston, 1.6 miles above, 1,740 feet below milepost 38, on west end of brick culvert, on center of first brick north of center joint; highest point in square cut on brick (U. S. Corps of Engineers t. b. m. 162)

Livingston, in public square on corner of Washington and Market streets, in northeast corner of office building of probate judge, on east fuce, 9 inches from corner and in seventeenth course of brick above projection at ground; copper bolt lettered "U. S. $\odot$ P. B. M." (U. S. Corps of Engineers p. b. m. 24)

Livingston, 0.8 mile below, on south pier of bridge over Sucarnochee Creek, on west end of pier on southeast corner of capstone, 5 inches from north face and 5 inches from west end; copper bolt, lettered “U. S. $\odot$ P. B. M." (U. S. Corps of Engineers p. b. m. 25) CUBA QUADRANGLE.

York along Alabama Great Southern R. R. to Cuba.

York, 3 miles above, 490 feet below milepost 30 from Meridian and section post 43-44, at north end of curve, on tangent post consisting of a piece of railroad iron 5 feet long set 3 feet in ground; point in northwest quarter of cross (U. S. Corps of Engineers t. b. m. 172)

York, 1.4 miles above, 615 feet below milepost 28 from Meridian, on west end of brick culvert, on sixth brick from south end; highest point of square cut in brick (U. S. Corps of Engineers t. b. m. 175)

York, 490 feet below station and directly below intersection of Alabama Great Southern R. R. and Southern Ry., on east end of stone culvert, south side, on first step below coping, 5 inches from east end and $3 \frac{1}{2}$ inches from north face; copper bolt, lettered "U. S. $\odot$ P. B. M." (U. S. Corps of Engineers p. b. m. 26)

York, 1.6 miles below, 820 feet above milenost 25 from Meridian, at south end of long tangent begiuning at water tank one-half mile below York, on south side of track, on iron tangent post, on point in southeast quarter of cross (U S. Corps of Engineers t. b. m. 179) -

York, 3.8 miles below station, 230 feet north of milepost 23 from Meridian, on west end of brick and double tile culvert, on center brick between two tiles; highest point of square cut in brick (U. S. Corps of Engineers t. b. m. 182)

Cuba, about 400 feet below station, on rear property line stone of Alabama Great Southern R. R., 100 feet north of track, in front of Holiness Church and opposite the jug factory ; copper bolt, lettered “U. S. $\odot$ P. B. M." (U. S. Corps of Engineers p. b. m. 27) ---

Cuba, 1.6 miles below, 975 feet below milepost 19 from Meridian, at west end of cut around sharp curve, on north end of brick and tile culvert; highest point in square cut in cement over center of tile (U. S. Corps of Engineers t. b. m. 188)

Feet. 239. 228

267.178

235. 659

182. 306

160.530

122. 062

140. 165

160. 579

155. 661

159. 585

166. 942

214. 660 
BELLAMY QUADRANGLE.

At Coatopa.

Coatopa, in southeast corner of Parker's store, in sixteenth course of brick from ground and sixth from south corner; coppei bolt (U. S. Corps of Engineers p. b. m. 1)

Feet. 126. 218

DEMOPOLIS QUADRANGLE.

McDowell along Southern Railway to Demopolis.

MIcDowell, on pedestal stone of water-tank foundation, on northeast corner of northeast stone of north quadrilateral, 8 inches from east face and 6 inches from north face of stone; copper bolt lettered "U. S. $\odot$ P. B. M." (U. S. Corps of Engineers p. b. m. 2)

McDowell, 0.8 mile east of, on south end of west pier of bridge over Tombigbee Rirer, in coping, 8 inches from east face; top of copper bolt iettered "U. S. $\odot$ P. B. M." (U. S. Corps of Engineers p. b. m. 3) -

McDowell, 0.8 mile east of, on north end of enst pier of bridge over Tombigbee River, in coping stone; copper bolt, lettered "U. S. $\odot$ P. B. M" (U. S. Corps of Engineers p. b. m. 4)

Demonolis, on Washington Street, opposite fire department station, at front entrance of Demopolis Inn, on east end of iron doorsill (formerly the Royal Hotel), on raised letters cast on sill, "Progress Manufacturing Company, Meridian, Miss."; center of the are " $\mathrm{C}$ " (U. S. Corps of Engineers b. m. "Old B. M.")

Demopolis, on southeast corner of Walnut and Capitol streets, on northwest corner of Mayer Block, on north end of base stone under north window, $6 \frac{1}{2}$ inches above sidewalk and $6 \frac{1}{2}$ inches south of buttress; copper bolt, lettered “U. S. ๑ P. B. M." (U. S. Corps of Engineers p. b. m. 5)

Demopolis, on northeast corner of Washington and Strawberry streets, on southenst corner of Cheshire Webb Building, on east end of base stone under window east of east entrance, 6 inches above sidewalk; copper bolt, lettered “U. S. ๑ P. B. M." (U. S. Corps of Engineers p. b. m. 6)

\section{VINEGAR BEND QUADRANGLE.}

Milepost 58 along Mobile \& Ohio R. R. to Escatawpa.

Escatawpa, in south chimney of Dr. IV. H. Boykin's house on Main Street, in center of middle brick in eleventh layer above watertable course; copper bolt (C. \& G. S. G-2)

Milepost 58, in white marble block set on top of small hill on east side of track, 30.9 meters at right angles from center of track, and 27.5 meters at right angles to track from milepost; block projects about an inch above ground; bottom of 1-inch square cavity (C. \& G. S. $\mathrm{H}-2)$

\section{DEER PARK QUADRANGLE.}

At Deer Park.

Deer Park, in white marble block, set in front yard of James B. Rawl's residence between schoolhouse and well, projecting 1 inch above ground; bottom of a cavity 1 inch square and one-half inch deep (C. \& G. S. F-2)
95. 294

120.183

126.002

127.013

175.880

215.400

153. 975 
CALVERT QUADRANGLE.

Milepost 38 along Mobile \& Ohio R. R. to Citronelle.

Milepost 38, in top of white marble marking stone in ground on east side of track, 7.78 meters from center of track and 0.81 meter from wire fence; bottom of square cut (C. \& G. S. E-2)

Feet. 235. 401

Citronelle, in south chimney of cottage belonging to Mobile \& Ohio R. R., in middle of brick in fourth layer from ground, three bricks from east edge of chimney and three from west edge; center of cross on head of copper bolt (C. \& G. S. "B")

330. 775

MOBILE QUADRANGLE.

Mobile along Louisville \& Nashville R. R. to St. Elmo.

Mobile, on sill of window on north front and near east end of customs-house, 0.215 meter from extreme north edge of sill, 0.143 meter from south wall, 0.145 meter from east wall, and 1.155 meters below window; bottom of square cut in stone (C. \& G. S. "A")

Mobile, in Bienville Park; old hydrographic bench mark at old astronomical station

St. Flmo, in yard of station and in northwest angle of house occupied by Mr. Adams; bottom of square cavity cut in top of marble post, 6 by 4 inches on top and about $2 \frac{1}{2}$ feet long, which has letters “U. S. C. S." cut upon top (C. \& G. S. A-1)

GRAND BAY QUADRANGLE.

\section{At Grand Bay.}

Grand Bay, on north side of chimney at east end of frame dwelling owned by Oscar Cassebry, in eighth layer of bricks above ground and near middle of third brick from north end of chimney; copper bolt (C. \& G. S. "B") 


\section{APPENDIX B.}

\section{SECONDARY ELEVATIONS.}

Secondary elevations from records and topographic maps of the United States Geological Survey and other useful elevations, includ: ing altitudes determined by vertical angles and other methods, are given below. These elevations are approximate only and should not be used for accurate work.

\begin{tabular}{|c|c|c|c|}
\hline Locality. & Quadrangle. & County. & $\begin{array}{l}\text { Eleva- } \\
\text { tion. }\end{array}$ \\
\hline Andeluvia Mountain. & Talladega. & Talladega. & Feet. \\
\hline Ashland. ............ & Ashland.. & Clay....... & $\begin{array}{l}1,134 \\
1,080\end{array}$ \\
\hline Ashville.... & Springville. & Etowah.................... & 680 \\
\hline Aurora Mountain triangulation station......... & Gadsden... & 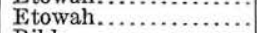 & 1,404 \\
\hline 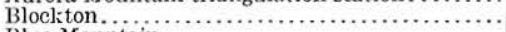 & Brookwood & 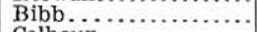 & 403 \\
\hline I3lue Mountain...... & Anniston. & Calhoun.............. & 1,500 \\
\hline 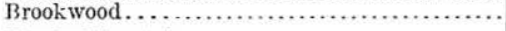 & Brookwood & Tuscaloosa & \\
\hline 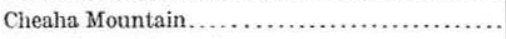 & Ashland. & $\left\{\begin{array}{l}\text { Clay ..... } \\
\text { Talladeg }\end{array}\right.$ & 2,407 \\
\hline Choccolocco Mountain. & Anniston. & Calhoun. & 2,074 \\
\hline Clanton.............. & Clanton... & Chilton... & 594 \\
\hline Clevcland... & Bessemer special. & Jefferson............. & 565 \\
\hline n.................. & Bessemer special...... & Shelby ................ & 380 \\
\hline Comnellsville Junction . . . . . . . . . . . . . . . & Brookwood. & Jefferson............. & 455 \\
\hline Cottondale............ & Brookwood. & Tuscaloosa............ & \\
\hline Double Mountain... & Bessemer special. ..... & Shelby............... & 986 \\
\hline Dugger Mountain.. & Anniston ............. & Cleburne.............. & 2,130 \\
\hline Eden ................. & Springville.......... & St. Clair............. & \\
\hline Falliston ............... & Bessemer sp & Shelby .... & \\
\hline 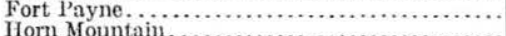 & Fort Payne........... & Dekalb................. & 924 \\
\hline $\begin{array}{l}\text { Iorn Mountain. } \ldots \ldots \ldots \ldots \ldots \ldots \ldots \ldots \ldots \ldots \ldots \\
\text { Ironaton. }\end{array}$ & & & 1,919 \\
\hline 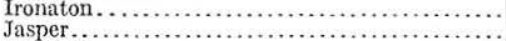 & 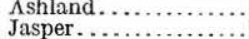 & 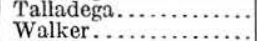 & $\begin{array}{l}735 \\
350\end{array}$ \\
\hline 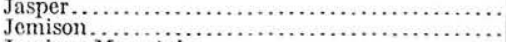 & $\begin{array}{l}\text { Jasper.......... } \\
\text { Clanton...... }\end{array}$ & & \\
\hline Jemison Mountinin... & Clanton... & 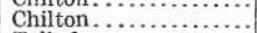 & 835 \\
\hline Kahatchee Mountain. & Talladega. & Talladega.. & 1,301 \\
\hline Lewisburg . ......... & Birmingham special... & Jefferson... & 507 \\
\hline Lineville.............. & Ashland. . & Clay ....... & 1,007 \\
\hline McGinty. . & Opelika.. & Chambers. & 666 \\
\hline Mobile Junctio & Bessemer special & Jefferson... & 510 \\
\hline Moore Gap. & Leeds. & $\left\{\begin{array}{l}\text { Jefierson } \\
\text { Shelby... }\end{array}\right.$ & 1,022 \\
\hline Moore Hill triangulation station. & Gadsder & Marshall. & 1,157 \\
\hline Mount Chandler.... & Springville. & Etowah.. & $1,5 \mathrm{CO}$ \\
\hline Mount Weisner. . . . & Fort Payne. & Cherokee. . & 1,900 \\
\hline Mount Zion.......... & Anniston.. & Calhoun... & 804 \\
\hline $\begin{array}{l}\text { Oakey Mount........... } \\
\text { Oak Mountain........ }\end{array}$ & Anniston.. & Cleburne... & 1,945 \\
\hline $\begin{array}{l}\text { Oak Mountain........ } \\
\text { Pilot Knoh.......... }\end{array}$ & Anniston... & Calhoun... & 1,727 \\
\hline $\begin{array}{l}\text { Pilot Knoh.............. } \\
\text { Plantersville......... }\end{array}$ & Leeds....... & Jefferson... & 1,144 \\
\hline 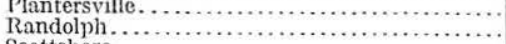 & $\begin{array}{l}\text { Cianton. } \\
\text { Clanton. }\end{array}$ & $\begin{array}{l}\text { Dallas...... } \\
\text { Bibb. }\end{array}$ & \\
\hline Scandolph.... & Scottsboro. & Jackson..... & 652 \\
\hline Scraper Mount:ill. . & Rome. & Cherokee. . & 1,629 \\
\hline Sedden............. & Springville. & St. Clair... & 500 \\
\hline Springville. . & Springville. & St. Clair. & 740 \\
\hline Summit Mountain triang & Gadsden... & Blount.. & 1,17 \\
\hline Thompson Gap. & Leeds. . & $\left\{\begin{array}{l}\text { Jefferson. } \\
\text { Shelby... }\end{array}\right.$ & 942 \\
\hline Turkey Heaven Mountuin. & Tallapoosa & Cleburne. & 1,648 \\
\hline Verbena.... & Clanton. & Chilton.... & 448 \\
\hline Woodstock. & Brookwood.. & Bibb...... & 51 \\
\hline
\end{tabular}




\section{INDEX.}

A.

\begin{tabular}{|c|c|c|}
\hline e. & & age. \\
\hline 31 & Cuba quadrangle... & 33 \\
\hline $28-33$ & Cullman.. & 27 \\
\hline 36 & Cullman quadrangle. . & $26-27$ \\
\hline 36 & Cunningham........ & 28 \\
\hline 7 & & \\
\hline 36 & D. & \\
\hline 36 & Decatur............ & 17 \\
\hline 36 & Decatur quadrangle $\ldots \ldots \ldots \ldots \ldots \ldots \ldots \ldots \ldots \ldots \ldots \ldots$ & 17 \\
\hline 36 & Deer Park................. & 34 \\
\hline & Deer Park quadrangle...................... & 34 \\
\hline 23 & 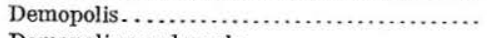 & 34 \\
\hline 24 & Demopolis quadrangle........................ & 34 \\
\hline $24-25$ & 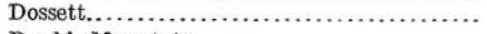 & 15 \\
\hline 29 & Double Mountain . ............................ & 36 \\
\hline 34 & Douglas, E. M., work of . ..................... & 5 \\
\hline 17 & Dugger Mountain............................. & \\
\hline 6 & - E. & \\
\hline & & \\
\hline
\end{tabular}

Akron.

$\Lambda$ labama Great Southern R. R .

Andeluvia Mountain.

Anniston quadrangle...

Arnold, C. W., work of.

Ashland.

Ashland quadrangle.

Ashville.

Aurora Mountain triangulation station

B.

Bainbridge.

................... 23

Barton................................. 24

Barton quadrangle....................... 24-25

Baylor.............................. 29

Bellamy quadrangle.......................

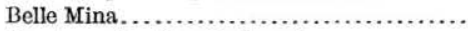

Bench marks, description of. plate showing.

Bessemer....................... 29

Bessemer quadrangle...................... 28-29

Bessemer special quadrangie............... 36

Bibbville................................ 29

Big Bear River......................... $\quad 26$

Birmingham ......................... 28

Birmingham quadrangle. . . . . . . . . . . 27-28

Birmingham special quadrangle............ 36

Blockton............................... 36

Blount Springs.......................... 27

Blue Mountain ........................... 36

Blue Water Creek........................ 20

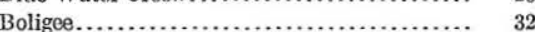

Bolivar................................ 13

Boyles.................................. 28

Bridgeport............................ 13

Brookwood............................. 36

Brookwood quadrangle................. 29-30, 36

Brownsboro........................... ${ }_{16}$

Browns Ferry ............................ 18-19

Bumpas Creek......................... 11

C.

Caivert quadrangle....................... $\quad 35$

Cedar Grove.............................. 14

Cheaha Mountain........................ 36

Cherokee.................................. 24, 26

Choccolocco Mountain..................... 36

Citronelle............................... 35

Clanton quadrangle $\ldots \ldots \ldots \ldots \ldots \ldots \ldots \ldots . . . \ldots \ldots$

Cleveland............................... 36

Coaling.................................... 30

Coalmont............................... 36

Coatopa................................. 34

Colbert Shoals canal...................... 26

Connellsville Junction...................... 36

Cottondale.............................. 30,36

Courtland.............................. 19

Cuba................................... 33

East Florence........................ 23

Eden.................................. 36

Elk River canal ........................ 18, 21

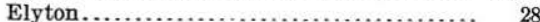

Englewood............................. 31

Epes................................. 32

Epes quadrangle......................... $32-33$

Escatawpa............................. 34

Eutaw .............................. 32

Eutaw quadrangle...................... $31-32$

\section{F.}

Fackler.............................. 14

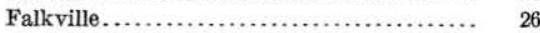

Falliston.............................. 36

Fearns................................. 16

Findleys Landing....................... 19

Flint................................... 17

Florence........................ 7-8, 9-10, 22-23

Florence quadrangle................. 7-10, 22-24

Fort Payne............................ 36

Fort Payne quadrangle................... 36

G.

Gadsden quadrangle....................... 36

Gannett, S. S., work of ................... 5

Garden City............................... 27

Grand Bay............................ $\quad 35$

Grand Bay quadrangle..................... 35

Greenbrier............................... 16

Green Hill............................. 9

Gunter triangulation station................... 15

Gurley................................ 16

H.

Hairston .............................. 32

Hanceville............................. 27

Hartsells............................... 26

Hillman................................ 29 


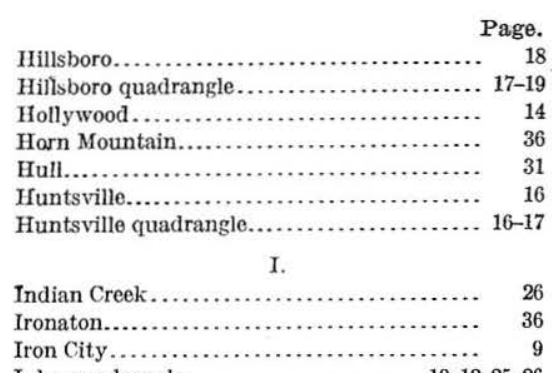

Iuka quadrangle................. 10-12, 25-26

J.

Jasper

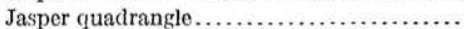

Jemison

Jemison Mountain

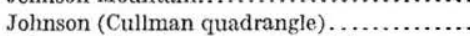

Johnson (Brookwood quadrangle).

Jonesboro

K.

Kehatchee Mountain.

Killen.

Kimbrell

L.

Larkinsville.

................. 14

I.eeds quadrangle.

Leighton.

Lewisburg

Lim Rock........................ 14-15

Lineville.......................... 36

Livingston......................... 33

Louisville \& Nashville R. R...... 16-17,26-28,35

M.

MeCalla..

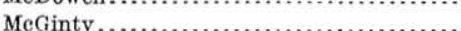

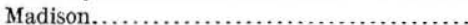

Maps of quacirangles in Alat ama, list of. ...

Margerum......................... 25,

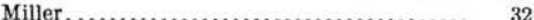

Miltons Bluff . . . . . . . . . . . . . . . . . 18

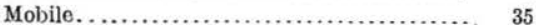

Mobile Junction .................... 36

Mobile quadrangle..................... 35

Mobile \& Ohio R. R . . . ............... 34, 35

Moore Gap............................. 36

Moore Hill triangulation station........... 36

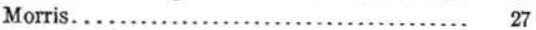

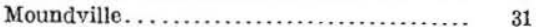

Mount Chandler.................... 36

Mount Weisner........................ 36

Mount Zion......................... 36

Muscle Shoals canal............ 19, 20,21,24

N.

Nashville, Chattanooga \& St. Louis Ry ..... Newcastle.

O.

Oak Mountain

Oakey Mount.

Opelika quadrangle.
P.

Page.

Paint Rock. ....................... 16

Parker............................. 33

Pilot Knob. . .......................... 36

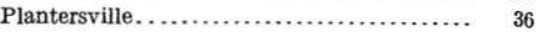

Powderly.......................... 28

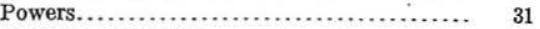

Powers quadrangle...................... 31

Pride. ........................ 22, 24-25

Pruitton....................... 8

$\mathrm{R}$.

Randolph.......................... 36

Reids............................ 27

Riverton........................ 11, 25, 26

Riverton Junction..................... ${ }_{25}$

Robinsons Landing. . . . . . . . . . . . . . . 18

Rogersville quadrangle................ 19-21

Rome quadrangle.................... 36

S.

St. Elmo ........................... 35

Sea level, mean, definition of.............. 6

Scottsboro..................... 14, 36

Scottsboro quadrangle. ............. 14-16, 36

Scraper Mountain . .................. $\quad 36$

Seddon............................ 36

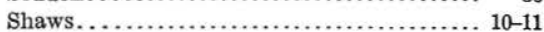

Sixmile Creek . ........................ 20

Southern Ry ....... 13-16,17-18, 19, 22, 24-25, 26,34

Springville........................ $\quad 36$

Springville quadrangle................. 36

Stevenson.............................. 13

Stevenson quadrangle................... 13-14

Summit Mountain triangulation station.... 36

Sutton, Frank, work of.............. 5

Swearengin......................... 15

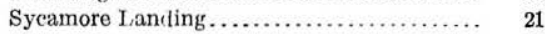

T.

Talladega quadrangle................. 36

Tallapoosa quadrangle.................. $\quad 36$

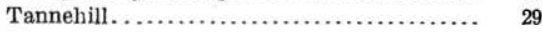

Thompson Gap....................... 36

Town Creek ............................. 19

Town Creek quadrangle.................. 19

Trinity . . . . . . . . . . . . . . . . . . . . .

Tuscaloosa quadrangle. ................ 30-31

Tuscumbia........................ 10,22

Tuscumbia quadrangle................ 10,22

Turkey Heaven Mountain.............. $\quad 36$

Turpin ................................ $\quad 29$

V.

Vance........................... 29-30

Verbena.............................. $\quad 36$

Vinegar Bend quadrangle............... 34

W.

Warrior.......................... 27

Warrior River...................... 31

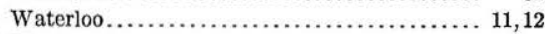

West End............................ 28

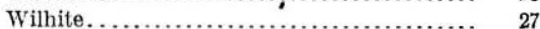

Woodstock....................... 29,36

Woodville............................ 15-16

$\mathrm{s}$.

York $\ldots \ldots \ldots \ldots \ldots \ldots \ldots \ldots \ldots \ldots \ldots \ldots, \quad 33$ 




Photomount

Pamphlet

Binder

Gaylord Bros. Inc.

Makers
Syracuse

PAT. JAN 21, 1908 
